Article

\title{
Novel Nematode-Killing Protein-1 (Nkp-1) from a Marine Epiphytic Bacterium Pseudoalteromonas tunicata
}

\author{
Nor Hawani Salikin $1,2, *(1)$, Malak Dubois ${ }^{3}$, Jadranka Nappi ${ }^{1}$, Helene Lebhar ${ }^{3}$, Christopher Marquis ${ }^{3}$ \\ and Suhelen Egan ${ }^{1, *}$ \\ 1 Centre for Marine Science and Innovation, School of Biological, Earth and Environmental Sciences, UNSW, \\ Sydney, NSW 2052, Australia; j.nappi@unsw.edu.au \\ 2 School of Industrial Technology, Universiti Sains Malaysia, USM, Gelugor 11800, Penang, Malaysia \\ 3 School of Biotechnology and Biomolecular Sciences, UNSW, Sydney, NSW 2052, Australia; \\ malak.dubois@det.nsw.edu.au (M.D.); h.lebhar@unsw.edu.au (H.L.); c.marquis@unsw.edu.au (C.M.) \\ * Correspondence: norhawani@usm.my (N.H.S.); s.egan@unsw.edu.au (S.E.)
}

check for updates

Citation: Salikin, N.H.; Dubois, M.; Nappi, J.; Lebhar, H.; Marquis, C.; Egan, S. Novel Nematode-Killing Protein-1 (Nkp-1) from a Marine Epiphytic Bacterium

Pseudoalteromonas tunicata.

Biomedicines 2021, 9, 1586.

https://doi.org/10.3390/

biomedicines 9111586

Academic Editor: Jun Lu

Received: 30 September 2021

Accepted: 22 October 2021

Published: 30 October 2021

Publisher's Note: MDPI stays neutral with regard to jurisdictional claims in published maps and institutional affiliations.

Copyright: (c) 2021 by the authors. Licensee MDPI, Basel, Switzerland. This article is an open access article distributed under the terms and conditions of the Creative Commons Attribution (CC BY) license (https:// creativecommons.org/licenses/by/ $4.0 /)$.
Abstract: Drug resistance among parasitic nematodes has resulted in an urgent need for the development of new therapies. However, the high re-discovery rate of anti-nematode compounds from terrestrial environments necessitates a new repository for future drug research. Marine epiphytes are hypothesised to produce nematicidal compounds as a defence against bacterivorous predators, thus representing a promising yet underexplored source for anti-nematode drug discovery. The marine epiphytic bacterium Pseudoalteromonas tunicata is known to produce several bioactive compounds. Screening heterologously expressed genomic libraries of $P$. tunicata against the nematode Caenorhabditis elegans, identified as an E. coli clone (HG8), shows fast-killing activity. Here we show that clone HG8 produces a novel nematode-killing protein-1 (Nkp-1) harbouring a predicted carbohydratebinding domain with weak homology to known bacterial pore-forming toxins. We found bacteria expressing Nkp-1 were able to colonise the C. elegans intestine, with exposure to both live bacteria and protein extracts resulting in physical damage and necrosis, leading to nematode death within $24 \mathrm{~h}$ of exposure. Furthermore, this study revealed C. elegans dar (deformed anal region) and internal hatching may act as a nematode defence strategy against Nkp-1 toxicity. The characterisation of this novel protein and putative mode of action not only contributes to the development of novel anti-nematode applications in the future but reaffirms the potential of marine epiphytic bacteria as a new source of novel biomolecules.

Keywords: anti-nematode; anthelminthic drugs; bioactives; Pseudoalteromonas tunicata; nematode; Caenorhabditis elegans; toxic protein

\section{Introduction}

Diseases resulting from parasitic helminth (nematode) infections are a global concern, especially for resource-limited countries with poor hygiene and an inadequate clean water supply [1,2]. Globally, approximately 1.5 billion people suffer from parasitic helminth infections, with the majority of cases occurring in East Asia, sub-Saharan Africa, America and China [3]. In humans, parasitic nematode infections are associated with malnutrition, anaemia, growth retardation, diminishing fitness, reduced cognition and result in numerous fatalities per year [2,4]. In addition to human illness, parasitic nematodes can also infect agricultural crops and aquaculture products, hence reducing yield and threatening food security $[5,6]$.

For the past 40 years, strategies to control parasitic nematodes have almost exclusively relied on intensive chemotherapy to relieve symptoms and diminish transmission. However, overuse and frequent parasite exposure to single broad-spectrum therapeutic drugs can increase the prevalence of anthelmintic resistance among harmful parasites [7-9] and therefore finding new anthelmintic compounds has become a matter of global urgency. 
The nematode Caenorhabditis elegans has been widely used as the surrogate organism for drug screening, as it shares many conserved genes and protein function with parasitic nematodes $[10,11]$ yet is easily maintained in the laboratory $[12,13]$.

Whilst the search for new candidate anthelmintic drugs is ongoing, marine-derived bioactive compounds particularly from surface-associated microbiota are a promising resource $[14,15]$. Bacteria from the genus Pseudoalteromonas have been recognised for their ability to produce a range of commercially and pharmaceutically relevant bioactivities against micro- and macrofoulers $[16,17]$. P. tunicata D2 is arguably the most comprehensively studied microorganism within the genus owing to its production of low- and high-molecular-weight compounds that are toxic against a wide spectrum of environmentally and medicinally relevant organisms including nematodes [18,19]. Functional screening of a P. tunicata D2 genomic fosmid library discovered a heterologous clone (designated HG8) that was toxic against the nematode C. elegans [18]. Genetic characterisation of HG8 revealed that a gene of unknown function (NCBI GeneBank Accession Number ZP_01132244.1) was partly responsible for its anti-nematode activity [18]. However, the heterologous expression of ZP_01132244.1 alone did not show significant anti-nematode activity (Ballestriero et al., unpublished data), suggesting that other genetic determinants are required for the nematode-killing activity.

Given the need for new anti-nematode drugs, the current study aimed to characterise and identify the bioactive agent responsible for the anti-nematode activity of the clone HG8 and its MOAs against C. elegans. Screening of the HG8 transposon mutant library identified a mutant of the HG8 clone (designated 7C8) showing attenuated anti-nematode activity due to the disruption of an uncharacterised gene designated HP1 (NCBI GeneBank Accession Number ZP_01132246.1). Analyses of the active clones revealed HP1 encodes for a novel protein designated nematode-killing protein-1 (Nkp-1) that harbours an N-terminal carbohydrate-binding module and has a putative mode of action similar to cry-like or aerolysin-like bacterial toxins. The discovery of this novel anti-nematode protein will hopefully contribute to the development of new therapies from the ocean that can be applied to parasitic nematode control management in the future.

\section{Materials and Methods}

\subsection{Bacterial Strains and Culture Conditions}

All bacterial strains and vectors used in this study are listed in Table 1. Unless otherwise stated, E. coli strains and other bacterial isolates were grown in lysogeny broth (LB10) and nematode growth media (NGM) [20] and were kept in 30\% $(v / v)$ glycerol at $-80{ }^{\circ} \mathrm{C}$. Solid media was prepared with the addition of $1.5 \%(w / v)$ of agar (Oxoid, Australia). Where required, $\mathrm{L}-(+)$-arabinose $(0.2 \% w / v)$ and antibiotics such as chloramphenicol $(12.5 \mu \mathrm{g} / \mathrm{mL})$, ampicillin $(50 \mu \mathrm{g} / \mathrm{mL})$ and kanamycin $(50 \mu \mathrm{g} / \mathrm{mL})$ were incorporated into the media.

Table 1. Bacterial strains and vectors used in this study.

\begin{tabular}{|c|c|c|}
\hline Strain or Vector & Relevant Characteristic or Genotype & Reference or Source \\
\hline \multicolumn{3}{|l|}{$\begin{array}{l}\text { Strain } \\
\text { E. coli. }\end{array}$} \\
\hline EPI300-T1R & 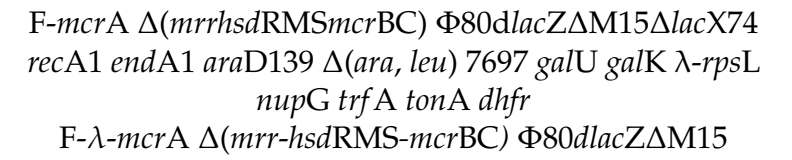 & Epicentre \\
\hline EPI300 & $\begin{array}{c}\Delta(\text { lac }) X 74 \text { recA1 endA1 araD139 } \Delta(\text { ara, leu }) 7697 \text { galU galK } \\
\text { rpsL (StrR) nup G' trf A dhfr }\end{array}$ & Epicentre \\
\hline OP50 & $\begin{array}{c}\text { Uracil auxotroph } \\
\phi 80 d l a c Z \Delta \mathrm{M} 15 \Delta(\text { lacZYA-argF)U169 recA1 endA1 hsdR17 }\end{array}$ & [20] \\
\hline $\mathrm{DH} 5 \alpha$ & $\begin{array}{c}(\mathrm{rk}-\mathrm{mk}+) \text { supE44 thi-1 gyrA relA1, carrying pBAD24 } \\
\text { vector }\end{array}$ & CMSI, UNSW \\
\hline
\end{tabular}


Table 1. Cont.

\begin{tabular}{|c|c|c|}
\hline Strain or Vector & Relevant Characteristic or Genotype & Reference or Source \\
\hline HP1 & $\begin{array}{l}\text { EPI300 transformed with pBAD24HP1 (NCBI Accession: } \\
\text { ZP_01132246.1) }\end{array}$ & This study \\
\hline BD24 & EPI300 transformed with empty pBAD24 vector & This study \\
\hline HG8 & $\begin{array}{l}\text { EPI300-T1R transformed with pCC1FOS } \\
\text { 01132230.1 to } \mathrm{ZP}_{-} 01132246.1\end{array}$ & [18] \\
\hline HP1::GFP & HP1 transformed with p519ngfp plasmid & This study \\
\hline BD24::GFP & BD24 transformed with p519ngfp plasmid & This study \\
\hline HG8::GFP & HG8 transformed with p519ngfp plasmid & This study \\
\hline 7C8 & $\begin{array}{l}\text { HG8 transposon mutant library showing mutation at } \\
\qquad H P 1\end{array}$ & {$[21]$} \\
\hline 7C8::HP1 & $\begin{array}{l}\text { HG8 transposon mutant library showing mutation at } \\
\text { ZP_01132246.1, complemented with pBAD24HP1 }\end{array}$ & This study \\
\hline 7C8::pBAD24 & $\begin{array}{l}\text { HG8 transposon mutant library showing mutation at } \\
\text { ZP_01132246.1, complemented with empty pBAD24 } \\
\text { vector }\end{array}$ & This study \\
\hline P. aeruginosa ATCC 9027 & Clinical sample & $\begin{array}{c}\text { American Type Culture Collection } \\
\left.\text { (ATCC }{ }^{\circledR}\right)\end{array}$ \\
\hline \multicolumn{3}{|r|}{ (IMT) f } \\
\hline 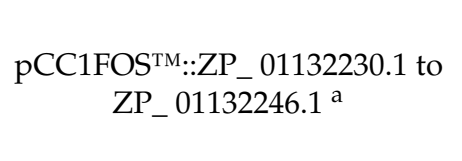 & $\begin{array}{c}\text { Fosmid backbone for genomic library of } \\
\text { Pseudoalteromonas tunicata D2 carrying a wild type D2 } \\
\text { insert (13.8 kb) expressing putative anti-nematode } \\
\text { activity, } \mathrm{Cm}^{\mathrm{r}}\end{array}$ & {$[18,22]$} \\
\hline $\begin{array}{c}\text { pCC1FOS }{ }^{\mathrm{TM}}:: \mathrm{ZP}_{-} 01132230.1 \text { to } \\
\text { ZP_01132246.1 with EZ-Tn5 }{ }^{\mathrm{TM}} \Delta \\
\text { ZP } 01132246.1^{\text {a }}\end{array}$ & $\begin{array}{l}\text { HG8 fosmid mutated by EZ-Tn5 }{ }^{\mathrm{TM}} \text { transposon on } P \text {. } \\
\text { tunicata wild type gene ZP_01132246, } \mathrm{Cm}^{\mathrm{r}}, \mathrm{Kan}^{\mathrm{r}}\end{array}$ & [21] \\
\hline pBAD24 ${ }^{a}$ & $\begin{array}{c}\text { F-, } \Delta(\arg \mathrm{F}-l a c) 169, \varphi 80 d l a c Z 58(\mathrm{M} 15), g \ln \mathrm{X} 44(\mathrm{AS}), \lambda^{-} \\
r f b \mathrm{C} 1, \operatorname{gyr} \mathrm{A} 96(\mathrm{NalR}), \operatorname{rec} \mathrm{A} 1, \text { endA1, spoT1, thiE1, hsdR17, } \\
\text { pBAD24 }\end{array}$ & [23] \\
\hline $\mathrm{pBAD}_{24 H P 1^{\mathrm{a}}}$ & $\begin{array}{l}\text { P. tunicata D2 wild type gene (ZP_01132246.1) cloned } \\
\text { downstream the pBAD promoter, } \mathrm{Amp}^{\mathrm{r}}\end{array}$ & This study \\
\hline p519ngfp & $\begin{array}{l}\text { High-copy-number plasmid with constitutive GFP } \\
\text { expression; } \mathrm{Km}^{\mathrm{r}}\end{array}$ & [24] \\
\hline
\end{tabular}

\footnotetext{
${ }^{\mathrm{a}}$ Inducible expression with the presence of L-arabinose $0.2 \%(w / v)$. CMSI denotes Centre for Marine Science and Innovation, University of
} New South Wales (UNSW).

\subsection{Maintenance and Synchronisation of Nematode C. elegans}

N2 strain Bristol C. elegans were maintained on NGM seeded with E. coli OP50 as the food source [20] and synchronised using fresh bleaching solution according to Stiernagle et al. [25].

\subsection{Generation of HG8 Mutant Libraries and Screening against C. elegans}

Transposon mutagenesis of the HG8 fosmid clone was performed using the EZ$\mathrm{Tn} 5^{\mathrm{TM}}<\mathrm{T} 7 / \mathrm{KAN}-2>$ promoter Insert Kit (Epicentre, Madison, WI, USA) as per the manufacturers' instructions. Successful mutants were screened on LB10 agar with chloramphenicol and kanamycin. Selected mutants were grown overnight in 96-well plates (Becton Dickinson Co Biosciences, Bedford, MA, USA) containing LB10 with antibiotics at $37^{\circ} \mathrm{C}, 60 \mathrm{rpm}$. Mutant libraries were replicated onto omnitory plates (Nunc brand, Germany) containing LB10 agar with antibiotics and L-(+)-arabinose (Sigma-Aldrich, St. Louis, MO, USA) using a 96 Solid Pin Multi-Blot Replicator tool (V\&P Scientific Inc.) followed by $48 \mathrm{~h}$ of incubation at $25{ }^{\circ} \mathrm{C}$. Synchronised L4 stage C. elegans (30-40 nematodes) were transferred onto the plate for selective grazing against the mutant libraries in triplicate. Colonies that were completely grazed after 4 days were then subject to a nematode-killing assay (described below) with the wild-type HG8 clone and a randomly selected non-toxic strain from the original P. tunicata fosmid library (BG6) [18] as the positive and negative controls, respectively. Non-toxic HG8 mutants resulting in $>60 \%$ C. elegans survival in the nematode-killing assay 
were sequenced bi-directionally by the Ramaciotti Centre for Genomics (University of New South Wales, Sydney, AU) for transposon mapping using the EZ-Tn $5^{\mathrm{TM}}<\mathrm{T} 7 / \mathrm{KAN}-2>$ promoter Insert Kit (Epicentre) Forward (5' ACCTACAACAAAGCTCTCATCAACC $3^{\prime}$ ) and Reverse (5'GCAATGTAACATCAGAGATTTTGAG $\left.3^{\prime}\right)$ primers.

\subsection{Cloning of P. tunicata Gene (HP1) into pBAD24 Vector}

The HP1 gene was amplified by PCR containing forward; $5^{\prime}$ ATGAGTACTACAATTTGGAACGATG $3^{\prime}$ and reverse primers; $5^{\prime}$ CTGGCTTGTTATCGCCATTT $3^{\prime}$ (10 pmol), DNA template (HG8 fosmid; 20 ng), Phusion ${ }^{\circledR}$ High-Fidelity PCR Master Mix with HF Buffer (NEB) and nuclease-free water (Ambion ${ }^{\circledR}$ Austin, TX, USA) up to $50 \mu \mathrm{L}$ of reaction volume and were run under a thermocycler condition of $98^{\circ} \mathrm{C}$ for $30 \mathrm{~s}, 30$ cycles of initial denaturation at $98^{\circ} \mathrm{C}$ for $30 \mathrm{~s}$, annealing at $60^{\circ} \mathrm{C}$ for $30 \mathrm{~s}$, extension at $72{ }^{\circ} \mathrm{C}$ for $30 \mathrm{~s}$ and a final extension at $72{ }^{\circ} \mathrm{C}$ for $7 \mathrm{~min}$. The amplicons were purified and phosphorylated using the T4 Polynucleotide Kinase (NEB) prior to blunt-ended ligation to the linearized pBAD24 vector, blunt-end repaired by the DNA Polymerase I, Large (Klenow) Fragment (NEB) and dephosphorylated at the $5^{\prime}$ end using the Shrimp Alkaline Phosphatase (rSAP) (NEB) as per the manufacturer's instructions. The phosphorylated amplicons were ligated alongside the pBAD24-NcoI-Klenow-rSAP treated vector using the T4 DNA ligase (NEB) and were transformed into the initially prepared electrocompetent E. coli EPI300 cells [26]. Transformants were recovered in SOC media and screened for successful recombinant clones on LB10 agar with ampicillin. Positive clones with correct insert DNA orientation were established by colony-pick PCR and submitted for sequencing analysis by the Ramaciotti Centre for Genomics, UNSW, Australia. Next, the recombinant vectors were transformed into the initially prepared electrocompetent 7C8 mutant cells [26] and were screened on LB10 agar with chloramphenicol, kanamycin and ampicillin. Colony-pick PCR was used to validate successful complementation and transformants were challenged against $C$. elegans using the nematode-killing assay.

\subsection{Nematode-Killing Assay}

Assay plates were seeded with an overnight culture of test bacteria $(30 \mu \mathrm{L})$ onto $35 \mathrm{~mm} \times 10 \mathrm{~mm}$ plates (SARSTEDT) containing LB10 agar with appropriate antibiotics and L-(+)-arabinose and were incubated at $25^{\circ} \mathrm{C}$ for four days. Thirty to forty synchronised L4 stage $C$. elegans individuals were transferred onto the test bacterial lawn and incubated at $25^{\circ} \mathrm{C}$. To assess C. elegans survival against the HP1 and HG8 crude protein extracts, a liquid anti-nematode assay was carried out in 24-well microtiter plates [27]. Wells were incorporated with $150 \mu \mathrm{L}$ of each protein extract (equivalent to $\sim 0.7 \mathrm{mg}$ of total protein content) supplemented with $40 \mu \mathrm{L}$ of concentrated E. coli OP50 (OD600 $\mathrm{nm}=2.0)$ and M9 buffer up to a final volume of $300 \mu \mathrm{L}$. Twenty to thirty L4 stage nematodes were transferred into each well of the 24-well microtiter plate and incubated in $25^{\circ} \mathrm{C}$ for $72 \mathrm{~h}$. The proportion of live nematodes were recorded every $24 \mathrm{~h}$ under the dissecting stereomicroscope (Olympus SZ-CTV). Nematodes were considered dead when they showed no response to touch (using sterilised worm picker). A test bacterial strain was considered toxic to C. elegans when more than $50 \%$ of the assayed nematodes were killed within 3 days [28]. Experiments were performed in triplicate and monitored until the maximum lifespan of the non-toxic control either E. coli OP50, E. coli EP300 or E. coli BD24 was reached.

\subsection{Egg Hatching and Brood Size Assay}

Assessment of C. elegans egg hatching and brood size following HP1, HG8 and BD24 bacterial exposure was investigated as described previously [29,30]. Nematode eggs were harvested via synchronisation [25] and eggs were pelleted through centrifugation at $1000 \times g$ for $10 \mathrm{~min}$ and resuspended in $1 \mathrm{~mL}$ of M9 buffer. Next, 60 eggs were inoculated onto each assay plate and incubated at $25^{\circ} \mathrm{C}$ for $7 \mathrm{~h}$. Numbers of L1 hatchlings on each plate were quantified under the dissecting microscope. To investigate the effect of HP1 and HG8 on C. elegans brood size, a single L4 stage nematode was transferred onto a nematode- 
killing assay plate containing a lawn of the test bacteria. The number of nematode progenies arising from an individual was quantified after $72 \mathrm{~h}$ incubation at $25^{\circ} \mathrm{C}$. The experiment was performed in triplicate.

\subsection{Bacterial Colonisation Assay}

HP1 and HG8 bacterial colonisation of C. elegans was determined as previously described [31,32]. L4 stage nematodes were washed from the NGM plates using the M9 buffer and were exposed to HP1::GFP, HG8::GFP and BD24::GFP strains on the LB10 agar. Thirty nematodes were picked from plates for each treatment (i.e., 10 worms/plate in triplicate) and used for microscopy analysis. The intensity of fluorescence signals from the acquired images were quantified using ImageJ (http:/ / rsbweb.nih.gov/ij/download.html. Accessed on 5 April 2020). Any observed morphological changes in C. elegans body structure, e.g., size reduction, pharynx distortion, degenerated internal organ, internal hatching or deformed anal region (dar), were recorded. To count the number of bacterial cells that colonised C. elegans, 10 live nematodes were picked after 6,12,24, 48, 72 and $96 \mathrm{~h}$ of assay and transferred onto the LB10 agar with gentamicin $(100 \mu \mathrm{g} / \mathrm{mL})$ to kill the surface-associating bacteria. Nematodes were washed with $10 \mu \mathrm{L}$ of LM buffer $(60 \mu \mathrm{g} / \mathrm{mL}$ levamisole in M9 buffer $)$ and then washed twice in LM buffer containing $100 \mu \mathrm{g} / \mathrm{mL}$ gentamicin and M9 buffer alone. The removal of surface bacteria was confirmed by inoculating the final M9 buffer wash onto the LB10 agar plates following an overnight incubation at $37^{\circ} \mathrm{C}$. Non-viable bacteria on the LB10 media indicated the successful removal of bacteria from the nematode surface. Washed C. elegans were transferred into a $1.5 \mathrm{~mL}$ microcentrifuge tube containing $200 \mu \mathrm{L}$ of phosphate buffer saline (PBS) with 1\% Triton X-100 and mechanically disrupted using a sterilized pestle. Nematode lysates were serially diluted in PBS and spread plated onto the LB10 agar with appropriate antibiotics. After an overnight incubation at $37^{\circ} \mathrm{C}$, the number of colonies were quantified and represented as colony-forming unit per nematode (CFU/nematode). Each experiment was performed in triplicate.

\subsection{Enzymatic Assay}

HP1, HG8 and BD24 overnight cultures and their protein extracts were assayed for a range of hydrolytic enzyme activities. Where relevant the bacterium Pseudomonas aeruginosa, which actively produces protease [33], lipase [34], gelatinase (collagenase) [35] and chitinase [36], was included as the positive control. LB10 broth or PBS was used as the negative control. Protease, lipase, gelatinase/collagenase and chitinase activities were assayed on prepared skim milk agar [37], gelatine agar [38], Tween 80 agar [39] and chitin agar [40], respectively. Fifty microlitres of bacterial cultures or their protein extracts were inoculated into the agar wells made using a sterilised cork borer (diameter size $8 \mathrm{~mm}$ ). Plates were incubated for 48 to $96 \mathrm{~h}$ at $25^{\circ} \mathrm{C}$. Positive enzymatic activity was indicated by the clearance zone observed surrounding the well. Each experiment was performed in triplicate.

\subsection{Necrosis Assay}

C. elegans exposed to HP1, HG8 and BD24 bacteria were assayed for necrotic cell death as described elsewhere $[41,42]$. Synchronized L4 stage C. elegans were washed from the $E$. coli OP50 lawn using the M9 buffer. Seventy to eighty nematodes were transferred onto the test bacterial lawn followed by incubation at $25^{\circ} \mathrm{C}$ for $48 \mathrm{~h}$. At least 30 nematodes per treatment ( 10 nematodes/replicate plate) were picked from the triplicate test bacterial lawns and washed twice in $20 \mu \mathrm{L}$ of M9 buffer. Nematodes were transferred into each well of a 96-well microtiter plate containing $10 \mu \mathrm{M}$ propidium iodide (PI) (Sigma Aldrich) in an M9 buffer and incubated in the dark at $25{ }^{\circ} \mathrm{C}$ for three hours. The animals were subsequently washed with M9 buffer and observed using a fluorescence microscope. $C$. elegans was confirmed as having necrosis when the dye was visualised in cells adjacent to the intestinal lumen due to loss of membrane cell integrity. The number of C. elegans showing necrosis were quantified. Each experiment was performed in triplicate. 


\subsection{Microscopy Imaging}

C. elegans images were acquired using an Olympus BX61 fluorescence microscope equipped with cellSens Dimension microscopy imaging software (Olympus). Slides containing live nematodes were prepared as previously described [43]. C. elegans were mounted onto the agarose pad ( $2 \% w / v$ in M9 buffer) using a sterilised worm picker and anesthetised with $10 \mu \mathrm{L}$ of levamisole ( $60 \mu \mathrm{g} / \mathrm{mL}$ in M9 buffer). To visualise the GFP-tagged bacterial colonisation within C. elegans, the Fluorescein Isothiocyanate (FITC) filter (excitation wavelength: $495 \mathrm{~nm}$, emission wavelength: $519 \mathrm{~nm}$ ) was used. Any morphological changes in the nematodes due to bacterial cells or their protein extracts exposure were inspected under the Differential Interference Contrast (DIC) filter. To determine any necrotic cell death, nematodes were observed under the Cyanine-3 (Cy3) filter (excitation wavelength: $550 \mathrm{~nm}$, emission wavelength: $570 \mathrm{~nm}$ ).

\subsection{Protein Extraction, SDS PAGE and Protein Modelling}

The HP1, HG8 and BD24 bacteria were cultured in $2 x$ yeast tryptone (2YT) broth with appropriate antibiotics. The $2 \mathrm{YT}$ culture media was seeded with a $0.6 \%(v / v)$ bacterial overnight culture, grown shaking $(200 \mathrm{rpm})$ at $37^{\circ} \mathrm{C}$ until the OD $(600 \mathrm{~nm})=0.6$ and thereafter heterologous gene expression was induced with L-arabinose at $25^{\circ} \mathrm{C}$ and $200 \mathrm{rpm}$ shaking condition for $18 \mathrm{~h}$. Cells were harvested via centrifugation at $6000 \times g$ for $7 \mathrm{~min}$ in $4{ }^{\circ} \mathrm{C}$, washed with an equal volume of ice-cold phosphate buffer saline (PBS) and kept in $-80^{\circ} \mathrm{C}$. Each of the cell pellets were resuspended in PBS and mechanically disrupted through ultra-sonication (Consonic, Australia) on ice for three minutes at 50\% amplitude with $2 \mathrm{~s}$ on and off interval. The resulting cell lysate was spun at $10,000 \times g$ for $30 \mathrm{~min}$ at $4{ }^{\circ} \mathrm{C}$. The supernatant-containing soluble cell fraction was removed and stored at $4{ }^{\circ} \mathrm{C}$ until further use. The remaining pellets (containing insoluble proteins) were washed twice each with ice cold Wash Buffer A (Triton $1000.5 \%$ v/v, Tris $5 \mathrm{mM}$, EDTA $50 \mathrm{mM}, \mathrm{pH}$ 8.0) and Wash Buffer B (glycerol 0.5\% v/v, Tris $5 \mathrm{mM}$, EDTA $50 \mathrm{mM}$, pH 8.0) before a double final wash with PBS at $4{ }^{\circ} \mathrm{C}$. The insoluble protein fraction was resuspended in PBS and assayed for anti-nematode activity using the 24-well microtiter plate assay method. Total protein content in each fraction was analysed using the Lowry method and quantified based on the standard curve generated from a serially diluted Bovine Serum Albumin (BSA) [44]. SDS PAGE was performed according to Laemmli's method $[45,46]$ using $12 \%$ polyacrylamide precast gel (BioRad). Protein bands of interest were excised from the gel and sent to the Bioanalytical Mass Spectrometry Facility (BMSF), University of New South Wales, Australia, for trypsin digestion and LC-MS analysis using ESI-TRAP. The peptide mass values were used for protein identification based on a MASCOT database search [47]. Advanced protein modelling, the prediction of ligand binding sites and intensive protein analysis by computational method was performed using Phyre2 [48] and SWISS-MODEL [49].

\subsection{Statistical Analysis}

The ordination of data and statistical analysis were performed using GraphPad Prism software 8.3.0 (GraphPad Software, La Jolla, CA, USA). C. elegans survival was analysed using the log-rank (Mantel-Cox) method [50,51] and a one-way ANOVA followed by Tukey's pairwise comparison test. Results for egg hatching, nematode brood size, bacterial colonisation and necrosis assay were analysed using a one-way ANOVA and Tukey's pairwise comparison test whilst the proportion of nematodes with morphological changes due to bacterial exposure and their protein treatment was analysed using a two-way ANOVA followed by Tukey's and Sidak's test. All results are presented as the means \pm standard error from triplicate samples. A $p$-value $<0.05$ was considered significant. 


\section{Results}

3.1. Generation of HG8 Transposon Mutants and Restoration of 7C8 Mutant Attenuated Activity upon Complementation with HP1

A total of $960 \mathrm{HG} 8$ transposon mutant clones were successfully generated and screened for diminished toxicity against C. elegans. In total, $69.8 \%$ (670 mutants) were not grazed by nematodes, $24.7 \%$ (237 mutants) were grazed at least in one replicate and the remaining $5.5 \%$ (53 mutants) were completely grazed in all three replicates (Figure 1A). To confirm the loss of anti-nematode activity for the grazed HG8 transposon mutants, 44 randomly chosen mutants from those that were grazed in at least one replicate were assessed for toxic activity using the nematode-killing assay. Approximately half $(21 / 44)$ of these mutants were considered non-toxic with $>60 \%$ nematode survival after 5 days. Five of the confirmed non-toxic mutants (denoted 8E10, 7C8, 1B11, 3B4 and 8D11) were randomly selected for transposon mapping. Sequencing of the DNA region directly adjacent to the transposoninsertion site revealed that mutant 8E10 was disrupted in the gene ZP_01132244.1 (Figure $1 B)$, whilst mutants 7C8, 1B11,3B4 and 8D11 were all disrupted in the neighbouring gene (NCBI Accession; ZP_01132246.1) which was then annotated as HP1 (Figure 1B). C. elegans exposed to the mutant clone expressing a functional HP1 in trans had reduced survival after 2 days compared to those exposed to the 7C8 mutant strain (one-way ANOVA followed by Tukey's test; $F(4,10)=239.9 ; p<0.0001$, Figure 1C) and a similar response as those exposed to the original toxic HG8 clone (one-way ANOVA followed by Tukey's test; F $(4,10)=239$.9; $p=0.0356$, Figure 1C).

\subsection{Expression of Individual HP1 in E. coli Reduced C. elegans Survival}

To further validate the toxicity expressed by the HP1 gene, the HP1 bacterial strain was assessed for its nematicidal activity against $C$. elegans. Exposure to HP1 after two days resulted in significant reduction in nematode survival compared to nematodes exposed to the non-toxic BD24 $(p=0.0006)$ and EPI300 control strains $(p=0.0007)$ (one-way ANOVA followed by Tukey's test; F $(3,8)=53.10$, Figure 1D). These observations further validated the toxicity of $H P 1$ against $C$. elegans.

\subsection{Exposure to HP1 and HG8 Does Not Affect C. elegans Eggs' Hatching Efficiency but Decreases the Brood Size}

There was no significant difference in the proportion of eggs hatching following exposure to HP1 or HG8 bacterial lawns compared to the non-toxic BD24 clone (one-way ANOVA followed by Tukey's test; F $(2,6)=0.4181 ; p=0.6891$ and $p=0.9908$, respectively, Figure 2A). However, the L1 larvae fed on HP1 and HG8 bacteria did not survive past $24 \mathrm{~h}$. To determine the impact of HP1 and HG8 on nematode brood size, a single C. elegans hermaphrodite was challenged against the toxic E. coli clones and the number of progenies resulting from the single nematode was quantified. A significant reduction in progeny was observed with both HP1 and HG8 strains compared to the number of progenies on the BD24 strain (one-way ANOVA followed by Tukey's test; F $(2,6)=169.7 ; p<0.0001$, Figure 2B). These findings suggest that both HP1 and HG8 did not affect $C$. elegans eggs' hatching efficiency; however, they were toxic to young progeny which resulted in diminishing $C$. elegans brood size. 

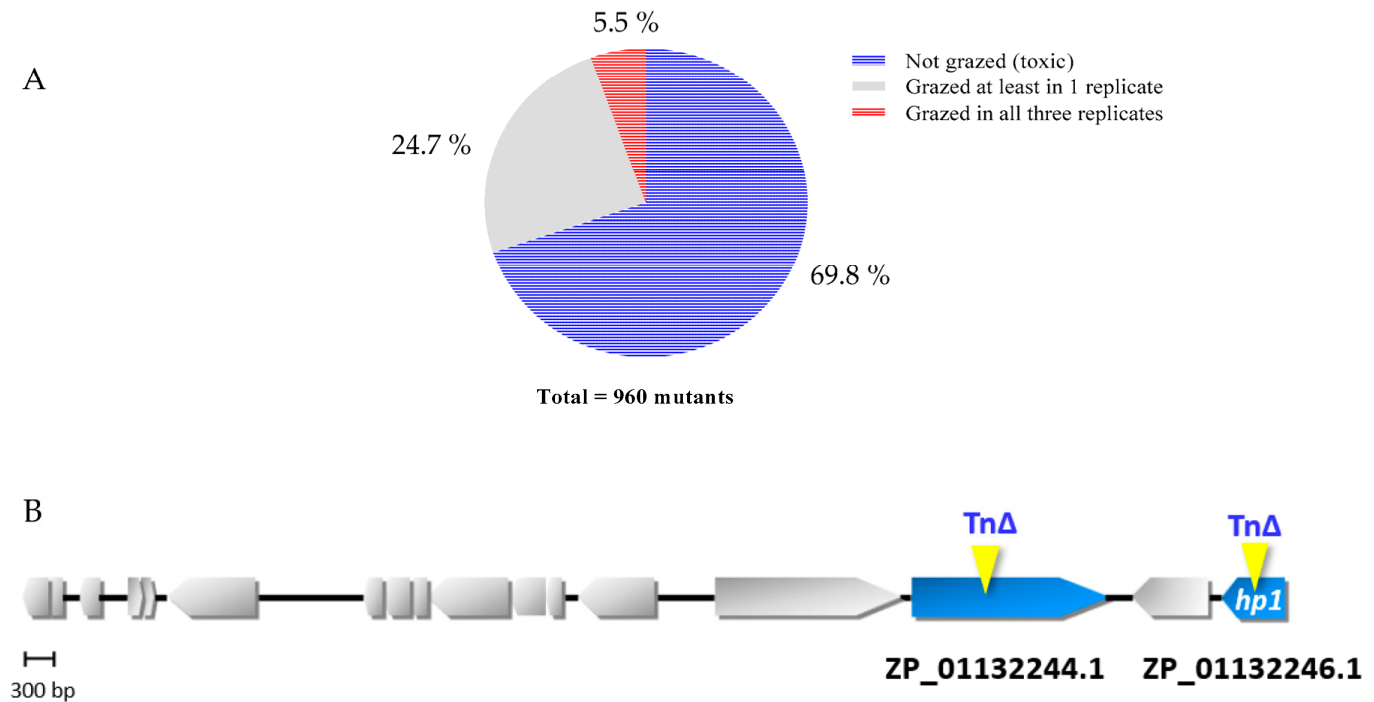

$300 \mathrm{bp}$

$13.8 \mathrm{~kb}$ P. tunicata insert
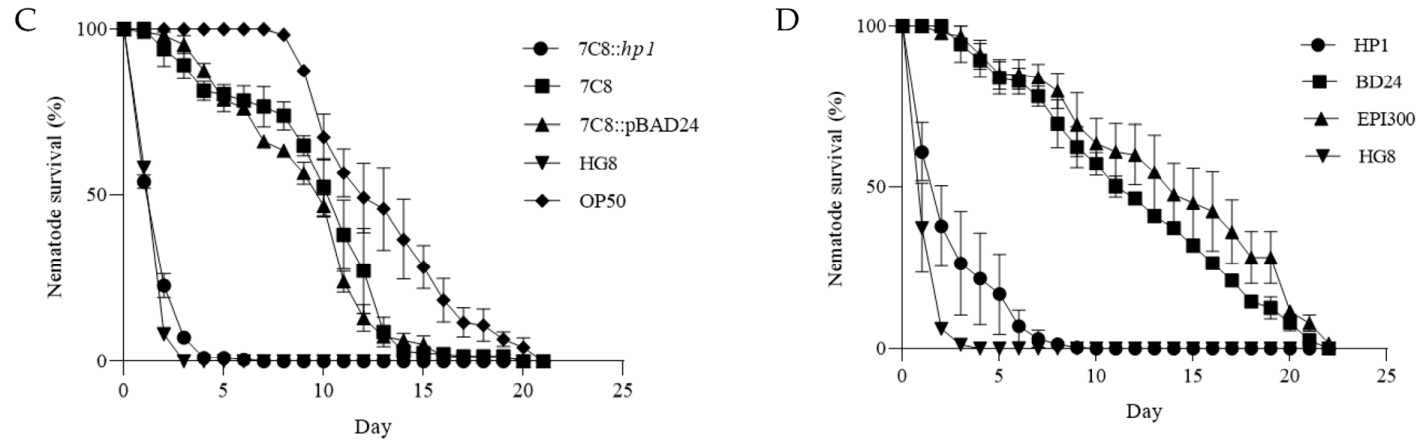

Figure 1. (A) The fraction of HG8 mutant libraries showing different levels of toxicity against C. elegans. (B) Transposon mutation in hypothetical proteins ZP_01132244.1 [18] and ZP_01132246.1 (denoted HP1) resulted in attenuated activity of HG8. (C) Complementation of 7C8 mutant with HP1 successfully restored the anti-nematode activity whilst in (D), individual expression of HP1 was also toxic against C. elegans compared to the non-toxic control BD24 and EPI300 bacterial strains. Significant differences among the treatments were detected (log-rank (Mantel-Cox) test; $p<0.0001$ ). Each data point represents means of nematode survival \pm standard error from triplicate samples.

A

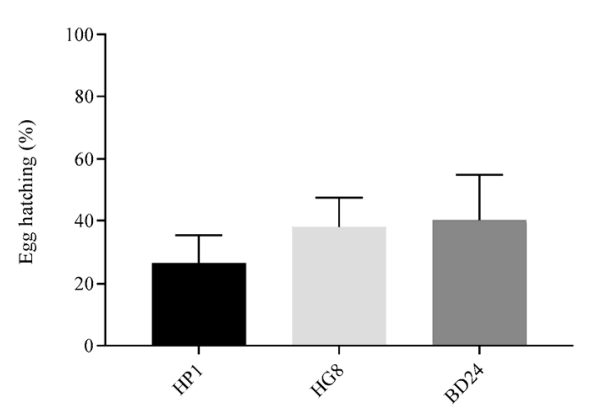

B



Figure 2. Effect of HP1, HG8 and BD24 bacterial exposure on (A) C. elegans egg hatching efficiency and (B) C. elegans brood size. No significant difference was observed on the proportion of C. elegans eggs hatching on HP1 and HG8 compared to BD24 bacterial strains $(p>0.05)$. However, the number of $C$. elegans progeny on the HP1 and HG8 bacterial lawn was significantly reduced compared to the BD24 non-toxic control $(p<0.0001)$. Results shown represent means \pm standard error from triplicate samples. 


\subsection{HP1::GFP and HG8::GFP Bacterial Strains Can Colonise and Persist in C. elegans Gastrointestinal System}

Quantification of GFP-labelled fluorescence after $24 \mathrm{~h}$ demonstrated a significantly higher degree of colonisation for strains HP1::GFP $(p=0.0044)$ and HG8::GFP $(p=0.0002)$ compared to the non-toxic BD24::GFP control strain (one-way ANOVA followed by Tukey's test; $F(2,6)=42.57$, Figure $3 \mathrm{~A}$ ). The relative fluorescence increased for these strains over the course of the experiment but remained undetected for controls (Supplementary Materials, Figure S1) suggesting HP1 and HG8 can colonise and persist in the nematode gut. To more accurately quantify the number of HP1::GFP and HG8::GFP cells colonising the nematode gastrointestinal system, the nematode lysate was cultivated on LB10 agar. After $6 \mathrm{~h}$ of exposure to the bacterial strains, no significant differences were observed between the number of HP1::GFP and HG8::GFP bacterial colonies compared to BD24::GFP (one-way ANOVA followed by Tukey's test; F $(2,6)=2.586 ; p=0.7434$ and $p=0.1432$, respectively, Figure 3B). However, the number of CFUs (colony-formation units) of HP1::GFP and HG8::GFP increased after $24 \mathrm{~h}$. The highest number of HP1::GFP and HG8::GFP CFUs were counted after $96 \mathrm{~h}$ of exposure with a higher bacterial load in nematodes treated with HG8::GFP (one-way ANOVA followed by Tukey's test; F $(2,6)=44.09, p=0.0090$; Figure 3B). In nematodes exposed to HP1::GFP and HG8::GFP bacterial load increased 12 -fold and 15-fold, respectively, at $96 \mathrm{~h}$ of exposure compared to the initial CFU at the 6-hour time point. In contrast, the number of the BD24::GFP strain increased only twofold after $96 \mathrm{~h}$. This finding is in agreement with microscopic observation showing a higher abundance of HP1::GFP and HG8::GFP bacteria in the C. elegans gastrointestinal system compared to the negative control BD24::GFP strain (Supplementary Materials Figure S1).

A

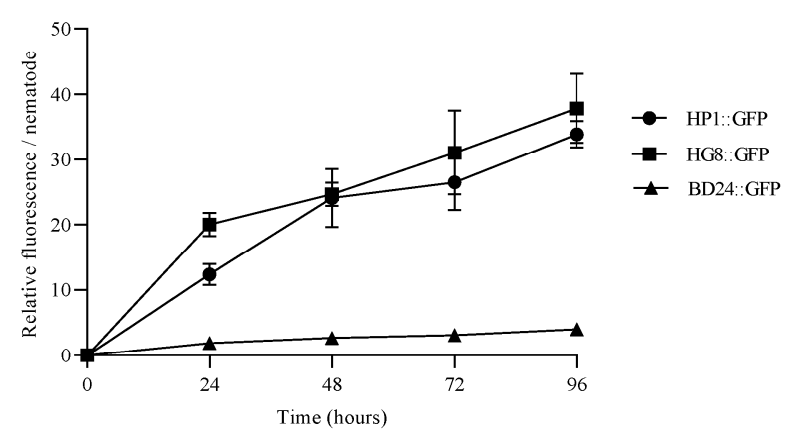

B

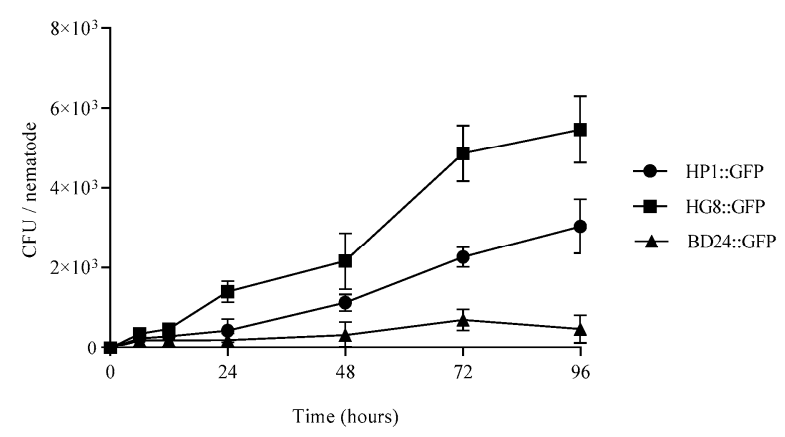

Figure 3. (A) Relative fluorescence representing the colonisation of HP1::GFP, HG8::GFP and the control strain BD24::GFP within C. elegans body. Data is presented as the mean of relative fluorescence from triplicate samples \pm standard error. (B) Bacterial colonisation assay of HP1::GFP, HG8::GFP and BD24::GFP against C. elegans. Number of viable bacteria in the C. elegans gastrointestinal system is shown as colony-formation unit (CFU)/nematode. Data is presented as the mean of colony-formation unit per nematode (CFU/nematode) from triplicate samples \pm standard error.

\subsection{Exposure to HP1::GFP and HG8::GFP Resulted in Morphological Changes in C. elegans}

Adult nematodes treated with the non-toxic control BD24::GFP showed a normal body length $(\sim 1.0 \mathrm{~mm})$, a healthy pharynx, an intact internal organ, eggs without any evidence of internal hatching and a normal anal region (Figure 4A-D). Whilst a small accumulation of BD24::GFP cells was observed at the C. elegans pharynx lumen (indicated by faint green fluorescence before the grinder bulb), no morphological changes were observed within this region (Figure 4B). In contrast, C. elegans exposed to HP1::GFP and HG8::GFP strains showed evidence of physical changes including smaller body size, pharynx distortion, internal hatching and internal organ damage (Figure 4E-G). The growth of the C. elegans was retarded upon 24 h exposure to HP1::GFP and HG8::GFP indicated by body length reduction compared to the normal adult nematodes fed with BD24::GFP (two-way ANOVA followed by Tukey's test; F $(2,6)=179.4 ; p=0.0441$ and $p=0.0007$, 
respectively, Figure 4A,E,I) and remained small after $96 \mathrm{~h}$ compared to the control nematodes. Furthermore, an increase in pharynx distortion was observed in C. elegans exposed to both HP1::GFP and HG8::GFP and the proportion was higher in nematodes treated with HP1::GFP following 96 h of exposure (two-way ANOVA followed by Tukey's test; $\mathrm{F}(2,6)=17.36 ; p=0.0088$, Figure $4 \mathrm{~F}, \mathrm{~K})$. A higher proportion of internal hatching was also observed for $C$. elegans exposed to HP1::GFP compared to HG8::GFP after $96 \mathrm{~h}$ (two-way ANOVA followed by Tukey's test; F $(2,6)=17.36 ; p=0.0088$, Figure $4 \mathrm{~F}, \mathrm{~J})$. The proportion of nematodes with internal organ damage constantly increased until all of the nematodes exposed to HG8::GFP were damaged internally after $72 \mathrm{~h}$ (two-way ANOVA followed by Tukey's test; F $(2,6)=442.1 ; p=0.0033$, Figure 4G,L). Unlike the other morphological changes, a deformed anal region (dar) was only observed on C. elegans exposed to HP1::GFP (Figure 4H). Half of the HP1::GFP exposed- C. elegans displayed a dar morphology after $24 \mathrm{~h}$ and the proportion of nematodes showing dar increased until at $96 \mathrm{~h} \sim 93 \%$ of the nematodes had the dar morphology (two-way ANOVA followed by Tukey's test; $\mathrm{F}(2,6)=58.84 ; p=0.0092$ when compared to HG8::GFP, Figure 4M).
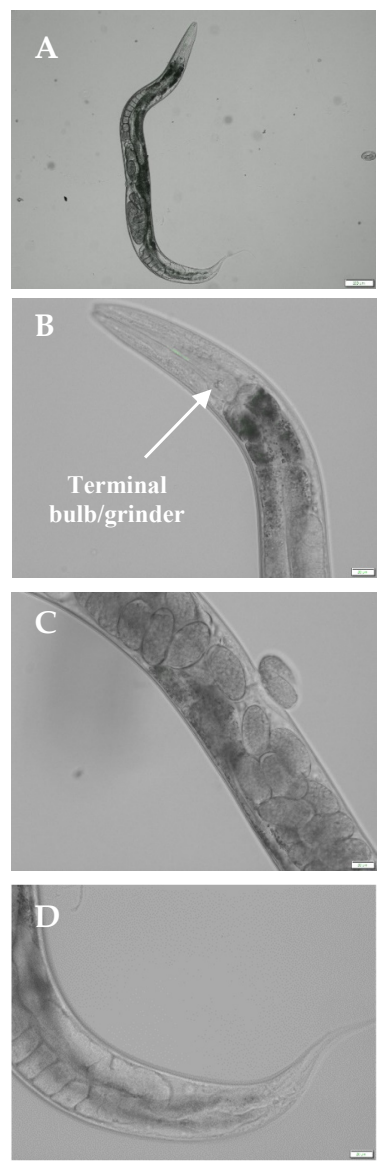
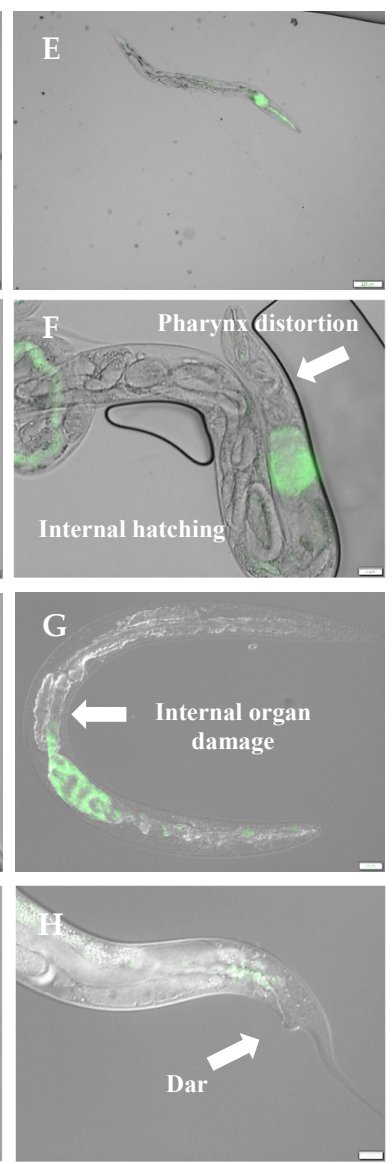

I
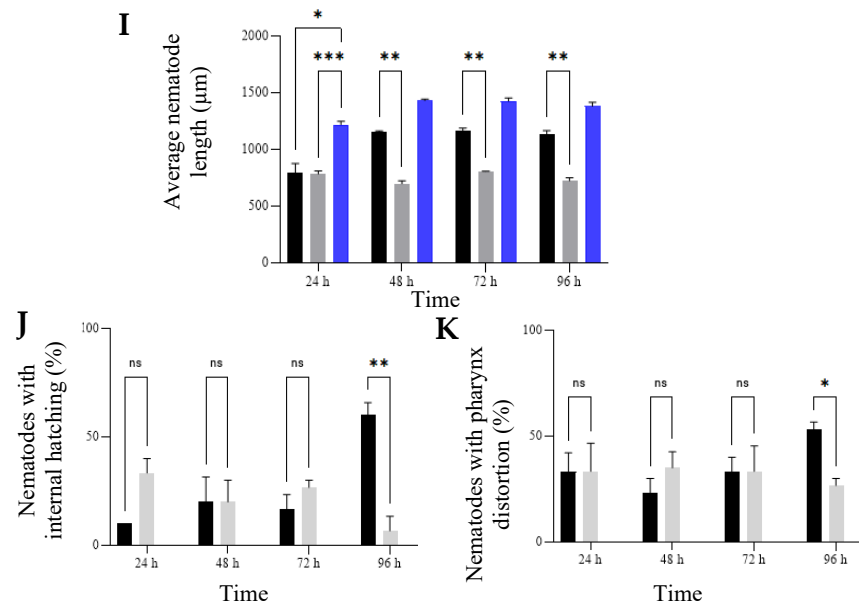

$\mathbf{L}$

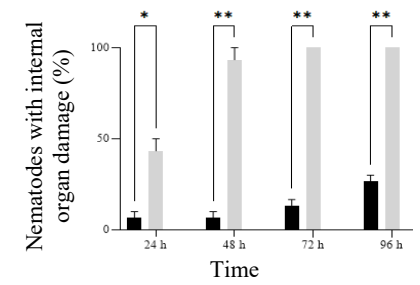

$\mathbf{M}$

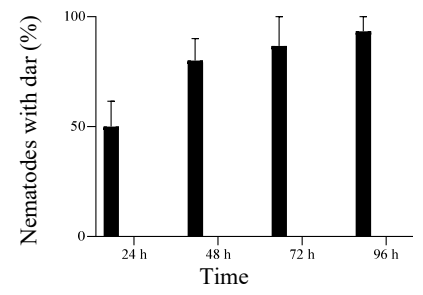

Figure 4. Examples of C. elegans body structure following exposure to HP1::GFP, HG8::GFP (E-H) and the non-toxic control BD24::GFP (A-D). Proportion of C. elegans with signs of morphological change after exposure to different GFP-tagged E. coli clones are shown in (I) (average nematode length), (J) (nematode with internal hatching), (K) (nematode with pharynx distortion), (L) (nematode with internal organ damage) and (M) (nematode with dar). Black, grey and blue bars indicate the proportion of morphological changes in C. elegans as a result of exposure to HP1::GFP, HG8::GFP and the non-toxic control BD24::GFP strains, respectively. Images of C. elegans were acquired using the DIC filter and the physical condition assessed for at least 30 worms per treatment. Graphical summaries represent the average percentage of assayed nematodes from triplicate samples \pm standard error $(n=3)$. A $p$ value $<0.05$ was considered as statistically significant. Significance levels are indicated on figures as follows; ${ }^{*} p<0.05,{ }^{* *} p<0.01,{ }^{* * *} p<0.001, \mathrm{~ns} p>0.05$. 


\subsection{Exposure to HP1::GFP and HG8::GFP Results in Loss of C. elegans Cell Membrane Integrity}

Pharyngeal and intestinal cells of nematodes exposed to the HP1 and HG8 strains showed evidence of a loss of cell membrane integrity indicated by the uptake of propidium iodide (Figure $5 \mathrm{~A}-\mathrm{F}$ ). In total, $\sim 81 \%$ and $\sim 97 \%$ of nematodes treated with HP1 and HG8 strains, respectively, showed loss of cell membrane integrity, whereas none of the nematodes exposed to control strain BD24 showed evidence of the phenotype (Figure 5P).

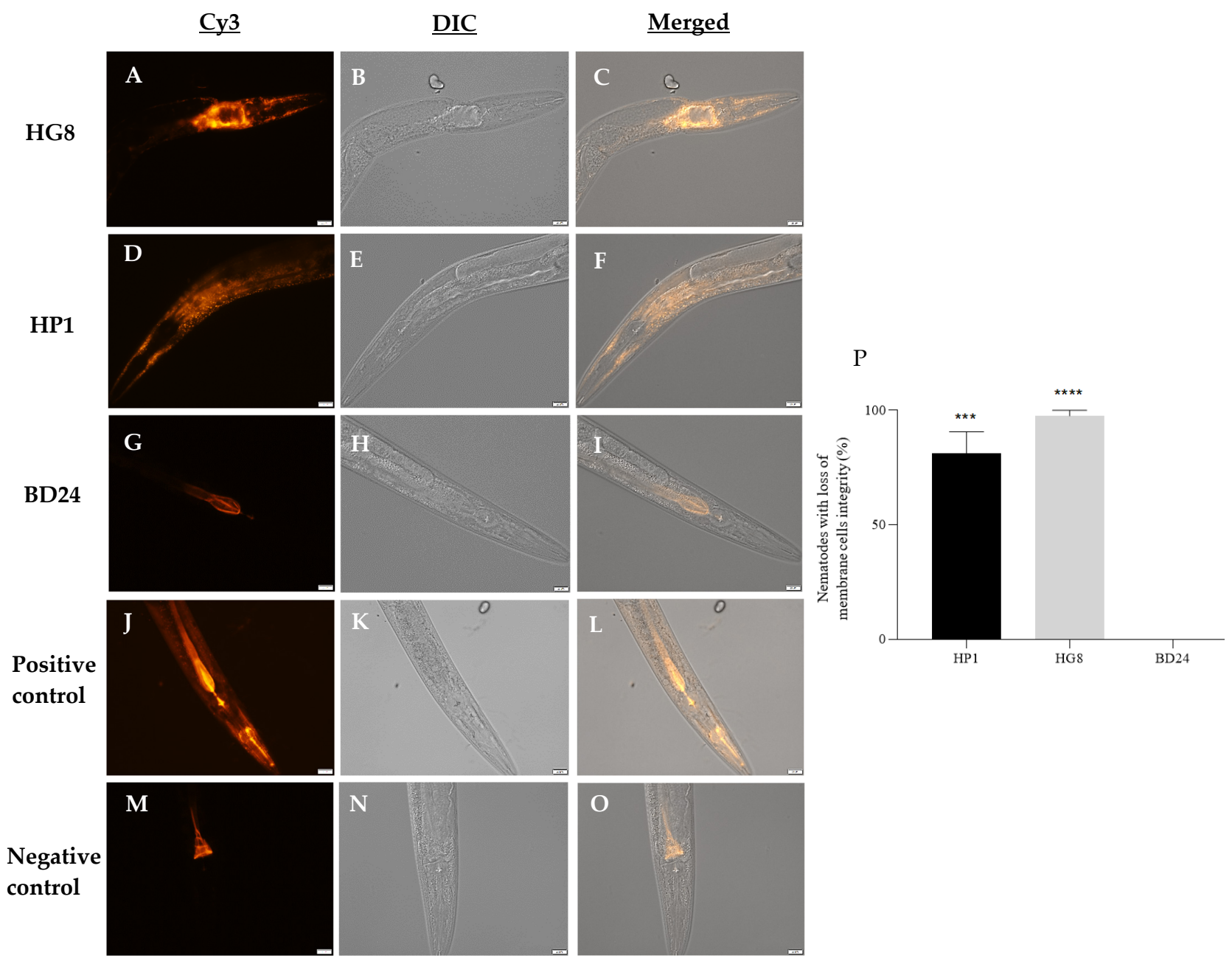

Figure 5. Propidium iodide (PI) staining on C. elegans exposed to HG8 (A-C), HP1 (D-F) and BD24 (G-I) strains. PI staining on nematodes exposed to excessive heating $(\mathbf{J}-\mathbf{L})$ and nematodes fed on E. coli OP50 (M-O) were used as the positive and negative controls, respectively. Nematode images were acquired under $40 \times$ magnification using the Cy3 filter (A,D,G,J,M) and DIC filters $(\mathbf{B}, \mathbf{E}, \mathbf{H}, \mathbf{K}, \mathbf{N})$. The captured images were then merged to give a precise visualisation of PI staining within the body of $C$. elegans $(\mathbf{C}, \mathbf{F}, \mathbf{I}, \mathbf{L}, \mathbf{O})$. Scale bars indicate $20 \mu \mathrm{m}$. The proportion of $C$. elegans showing loss of cell membrane integrity after $48 \mathrm{~h}$ of exposure to HP1 and HG8 bacteria was indicated in (P). No loss of cell membrane integrity was observed on C. elegans treated with the negative control BD24. Results are representative data of mean percentage of nematodes showing loss of cell membrane cells integrity from triplicate assays \pm standard error. ${ }^{* *}$ denotes $p=0.0001,^{* * * *}$ denotes $p<0.0001$.

\subsection{HP1 and HG8 Protein Extracts Are Toxic against C. elegans}

Despite HP1 and HG8 bacterial cell-free supernatant being non-toxic to C. elegans (data not shown), soluble and insoluble protein fractions were assessed for nematodekilling activity. After $48 \mathrm{~h}$, treatment with HP1 and HG8 protein fractions resulted in diminished C. elegans survival with toxic activity being more pronounced in the insoluble protein fraction (one-way ANOVA followed by Tukey's test; F $(6,14)=427.2 ; p<0.0001$, Figure 6). In contrast, C. elegans treated with the soluble and insoluble protein fractions of 
the non-toxic BD24 control clone had no impact on nematode survival (one-way ANOVA followed by Tukey's test; F $(6,14)=427.2 ; p=0.9783$, Figure 6$)$. These results suggest that the nematode-killing activity likely results from a proteinaceous compound associated with HP1 and HG8 bacterial cells. The toxic compound is hereafter denoted 'nematode-killing protein-1' (Nkp-1).

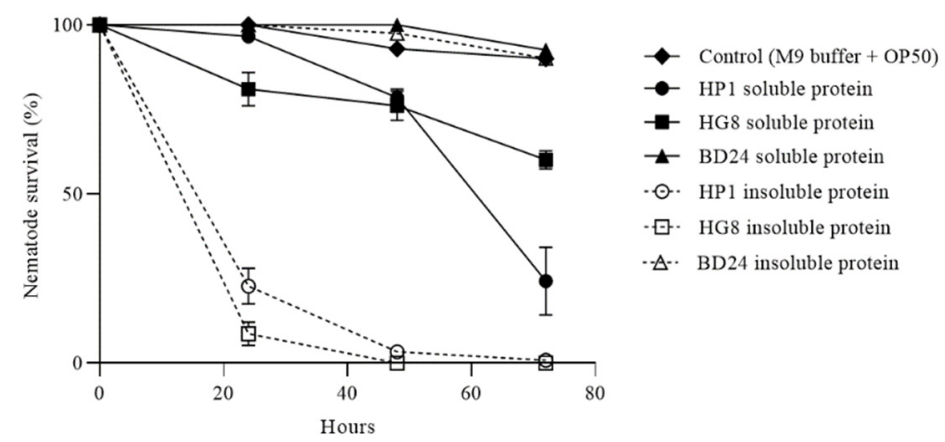

Figure 6. C. elegans survival in the soluble and insoluble protein fractions of HP1, HG8 and BD24 using the 24 -well microtiter plates. The total protein in each fraction was $\sim 0.7 \mathrm{mg} / \mathrm{mL}$. The non-toxic BD24 protein fractions and M9 buffer added with E. coli OP50 were used as the negative controls. Exposure to the HP1 and HG8 protein extracts reduced nematode survival with the decrease more pronounced in the insoluble compared to the soluble protein fraction for each strain $(p<0.0001)$. Each data point represents means of nematode survival \pm standard error from triplicate samples.

\subsection{Nkp-1 Treatment Causes Physical Damage to C. elegans Cells}

While C. elegans exposed to BD24 protein extract displayed a normal morphology (Figure 7A-D), nematodes exposed to either the soluble or insoluble protein of HP1 and HG8 strains after $72 \mathrm{~h}$ showed several morphological changes, i.e., body length reduction (indicating growth retardation), internal organ damage, pharynx distortion, vacuole formation and internal hatching (Figure 7E-H). The insoluble proteins from both clones negatively impact nematode growth (two-way ANOVA followed by Tukey's test; $\mathrm{F}(1,12)=10.47 ; p=0.0059$ and $p=0.0002$, respectively, Figure 7E,I) while treatment with the insoluble protein of HP1 resulted in a higher proportion of nematodes with pharynx distortion compared to nematodes exposed to protein extracts from HG8 (two-way ANOVA followed by Tukey's test; $\mathrm{F}(1,12)=0.2500 ; p=0.0262$ and $p=0.0056$, respectively, Figure $7 \mathrm{~K})$. An increase in vacuole formation was also observed for nematodes treated with the soluble protein of HP1 compared to the soluble protein of HG8 (two-way ANOVA followed by Tukey's test; $F(1,12)=25.00 ; p=0.0006$, Figure 7L). In addition, exposure to both protein fractions from HP1 resulted in a higher proportion of internal hatching in C. elegans compared to exposure to either protein fraction from HG8 (two-way ANOVA followed by Tukey's test; F $(1,12)=3.125, p=0.0083$ and $p<0.0001$, Figure $7 \mathrm{M})$. 

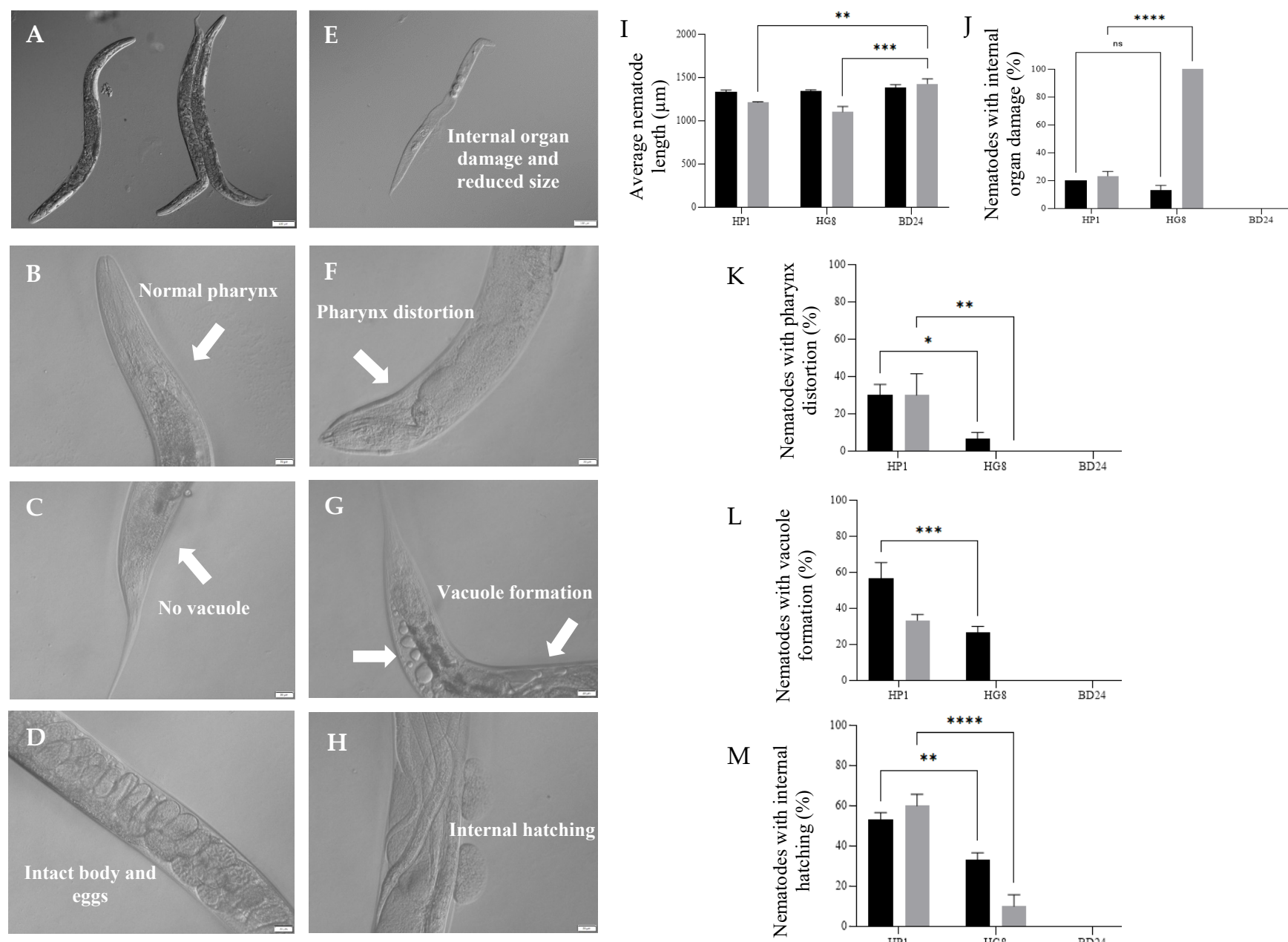

K
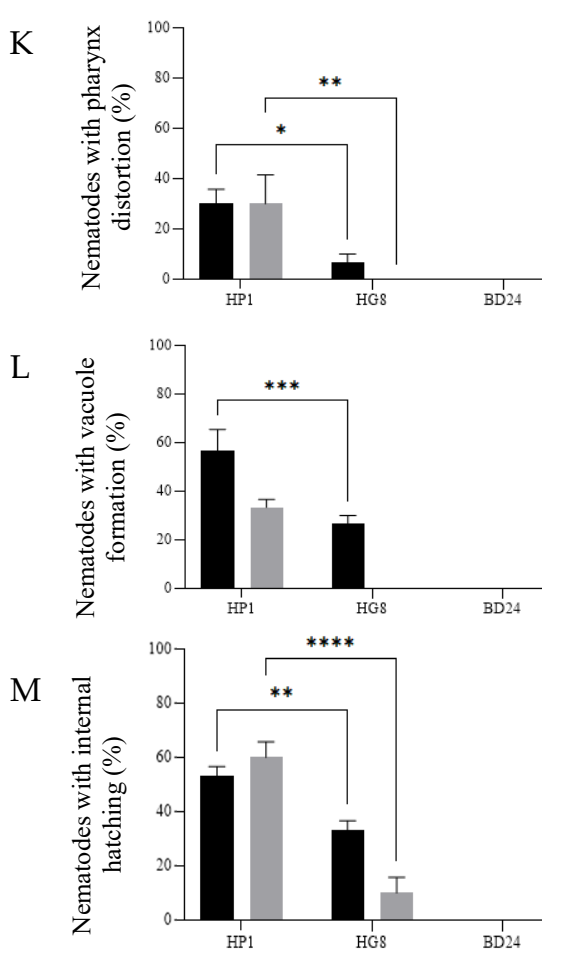

Figure 7. Examples of physical appearances observed on C. elegans treated with the total insoluble protein fractions of non-toxic BD24 (A-D) and Nkp-1 expressing strains (HP1 and HG8). Several morphological changes, i.e., reduced body size based on the average nematode length $(\mathbf{E}, \mathbf{I})$, internal organ damage $(\mathbf{E}, \mathbf{J})$, pharynx distortion $(\mathbf{F}, \mathbf{K})$ vacuole formation $(\mathbf{G}, \mathbf{L})$ and internal hatching $(\mathbf{H}, \mathbf{M})$ were observed for nematodes exposed to protein fractions of HP1 and HG8. Results shown are representative data from the mean percentage of nematodes with morphological changes from triplicate samples \pm standard error. A $p$ value $<0.05$ was considered statistically significant. Soluble protein: black; insoluble protein: grey. Significance levels are indicated on figures as follows: ${ }^{*} p<0.05,{ }^{* *} p<0.01,{ }^{* * *} p<0.001,{ }^{* * *} p<0.0001$, ns $p>0.05$.

\subsection{Nkp-1 Harbours a Carbohydrate-Binding Module}

Protein bands corresponding to the estimated size of Nkp-1 ( 25 kDa) were observed through SDS PAGE in the protein fractions of HP1 and HG8 strains (Supplementary Materials, Figure S2). These protein bands were excised from the gel and identified as Nkp-1 using LC-MS analysis.

The Nkp-1 protein sequence (consisting of $235 \mathrm{aa}$ ) was aligned to the sequences of closely related homologs of Nkp-1 (obtained from the BLASTp results, see Figure 8A) including the cholerae toxin from Vibrio cholerae [52,53] and a hypothetical protein from Bacillus halodurans (PDB ID: 1W9S) harbouring the carbohydrate-binding module [54]. Homology modelling of $\mathrm{Nkp}-1$ resulted in a 3D protein model (Figure $8 \mathrm{~B}$ ) based on the highest confidence scoring template, a $\beta-1,3$-glucan binding CBM6 module (galactosebinding domain-like, family 6 carbohydrate-binding module) of hypothetical protein BH0236 from B. halodurans (PDB ID: 1W9S) [54]. In total, 88 residues of Nkp-1 from residue 14 to residue 101 ( $37 \%$ of the $\mathrm{Nkp}-1$ sequence) located in the $\mathrm{N}$-terminal of the protein were modelled with $48 \%$ confidence (Figure $8 \mathrm{D})$. Over half (56\%) of the Nkp-1 aligned sequence were modelled as having a secondary structure consisting of anti-parallel 
beta strands or $\beta$ barrel, which is composed of tandem repeats that coil and twist to construct a closed toroidal structure. A second 3D model was built using SWISS-MODEL based on the PsCBM35-2 domain containing carbohydrate-binding module 35 (CBM35) of $\alpha-1,6$-glucosyltransferase (classified under the glycoside hydrolase (GH) family 31 alphaglucosidase) from Paenibacillus sp. 598K (PDB ID: 5X7O) [55] (Figure 8C). The alignment resulted in $23.8 \%$ identity from residue 16 to residue 105 (Figure $8 \mathrm{D}$ ).

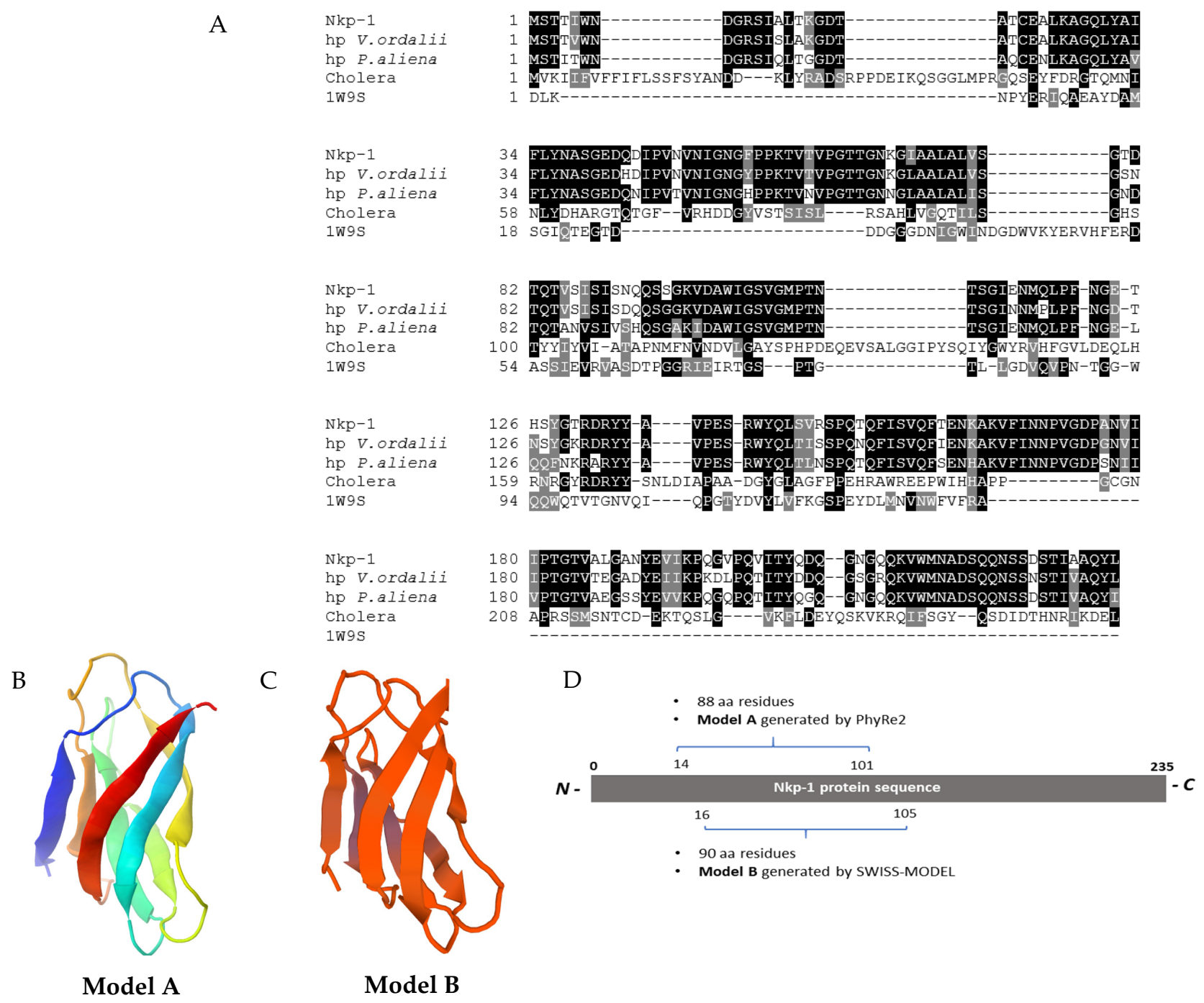

Figure 8. (A) Multiple sequence alignment of $\mathrm{Nkp}-1$ protein sequence and closely related protein sequences, including the uncharacterised hypothetical protein (hp) from V. ordalii and P. aliena and characterised protein sequences; Cholera Enterotoxin Subunit A from V. cholerae (denoted as Cholera) and a hypothetical protein BH0236 from B. halodurans (PDB ID: 1W9S) harbouring a $\beta$-1,3-glucan binding CBM6 module [54] (denoted as 1W9S). The total amino acid residues for each of the protein sequences are: Nkp-1 (235 aa), hp V. ordalii (235 aa), hp P. aliena (235 aa), Cholera (258 aa) and 1W9S (1020 aa). The consensus residues in each aligned protein sequence are highlighted in black and grey whilst the identified gaps may indicate deletion or insertion of amino acids. The sequence alignment was created using T-Coffee [56] and displayed using Boxshade (ExPASy). (B) Model A Nkp-1 was generated by PhyRe2 using the structure of beta-1,3-glucan binding CBM6 module of hypothetical protein BH0236 from Bacillus halodurans (PDB ID: 1W9S). The model dimensions (A): X:26.001 Y:40.693 Z:33.630 indicates the permitted rotation of the C-N bond in the polypeptide chain. (C) Model B Nkp-1 was generated by SWISS-MODEL using the structure of PsCBM35-2 domain containing carbohydrate-binding module-35 (CBM35) of $\alpha$-1,6-glucosyltransferase from Paenibacillus sp. 598K (PDB ID: 5X7O). The protein alpha helices are shown as arrows whilst the beta strands are shown as ribbons. The coil and turn protein are indicated in line. The arrowhead points towards the carboxy termini. (D) Nkp-1 protein coverage that is used by PhyRe2 and SWISS-MODEL to generate the Nkp-1 3D protein model A and B, respectively. 


\section{Discussion}

\subsection{HP1 Is Responsible for Nkp-1 Expression}

Sequencing and gene complementation of non-toxic mutant 7C8 revealed that the expression of a single gene, $H P 1$, was sufficient for toxic activity against $C$. elegans. The HP1 encodes for a novel nematode-killing protein ( $\mathrm{Nkp}-1)$, which is toxic to C. elegans in both soluble and insoluble forms. While the intact cells of Nkp-1-expressing E. coli were active against $C$. elegans, corresponding cell-free supernatants were non-toxic, suggesting that the concentration of Nkp-1 in the supernatant is too dilute or that the protein is not secreted to the environment. Other studies have observed nematode-killing compounds that are retained within the cell of the producers. For example, prodigiosin in Serratia marcescens cell extracts is toxic against the plant parasitic nematodes; Radopholus similis and Meloidogyne javanica [57] and the insoluble nematicidal Cry5B crystal protein was also purified from the intact cells of Bacillus thuringiensis [58].

Analysis of the Nkp-1 protein sequence led to the generation of two models (Model $\mathrm{A}$ and $\mathrm{B}$ ) both consisting of one of two different putative carbohydrate-binding modules (CBMs) (i.e., CBM6 or CBM35) (Figure 8B,C). The structural features of both carbohydratebinding modules are composed of canonical $\beta$-sandwich folds which are connected by loops of different length (http:/ / www.cazy.org/. Accessed on 20 May 2020) [59]. The CBM6 and CBM35 carbohydrate-binding modules are found in several enzymes, i.e., endoglucanase, $\beta$-agarase, $\alpha$-1,3-glucanase, glucuronoxylanase, esterase and mannanase [60-64] and bacterial toxins, i.e., crystal toxins (Cry) from Bacillus thuringiensis $[65,66]$. These carbohydrate-binding modules enable enzymes to bind to the target substrate [67] or toxins to bind to the membrane or glycoconjugate receptors of the target host cells $[65,68]$. As an example, insoluble Cry proteins produced by B. thuringiensis are potent nematicidal and pesticidal toxins that harbour the CBM6 and CBM35 carbohydrate-binding module [66,69]. The Cry toxins generally consist of three structural domains, where domain I is responsible for protein toxicity, domain II is associated with toxin binding to the host glycoconjugate receptor and domain III is important for both host receptor recognition and toxin binding $[65,70]$.

The Nkp-1 models harbouring the CBM6 (Figure 8B) and CBM35 modules (Figure 8C) consist of an antiparallel $\beta$-sandwich protein arrangement. This $\beta$-sandwich structure is thought to be key to the specificity of Cry toxin binding to the target nematode and insect's intestinal cell receptor $[65,71]$, with studies showing that swapping this structure between different Cry toxins results in altered specificity and toxicity of the toxin towards several target organisms [72,73]. The $\beta$-sandwich structure (domain III) is also important for Cry protein structural integrity and stability due to the network of hydrogen bond and van der Waals interactions between the protein residues and the side chains $[71,73]$ Given the similar arrangement of antiparallel $\beta$-sandwich in Nkp-1, it is possible that these carbohydrate-binding modules play a role in recognition and binding to one of the many glycoconjugate receptors present in the C. elegans intestine [68,74]. While the specific Nkp-1-targetting glycoconjugate receptor in C. elegans warrants further investigation, this discovery suggests the initial mechanism of $\mathrm{Nkp}-1$ killing activity against $C$. elegans involves attachment to the host membrane receptor, prior to the initiation of nematicidal activity.

\subsection{Nkp-1 Expressing E. coli Clones Kill C. elegans via a Proposed Step-by-Step Mode of Action (MOA)}

We observed that ingestion of Nkp-1 expressing bacterial strains results in morphological damage and cellular injury (necrosis) to the nematodes, leading to the animal's death. A step-by step mode of action model has been proposed to show the killing activity of Nkp-1 expressing bacteria against C. elegans (see Figure 9). 


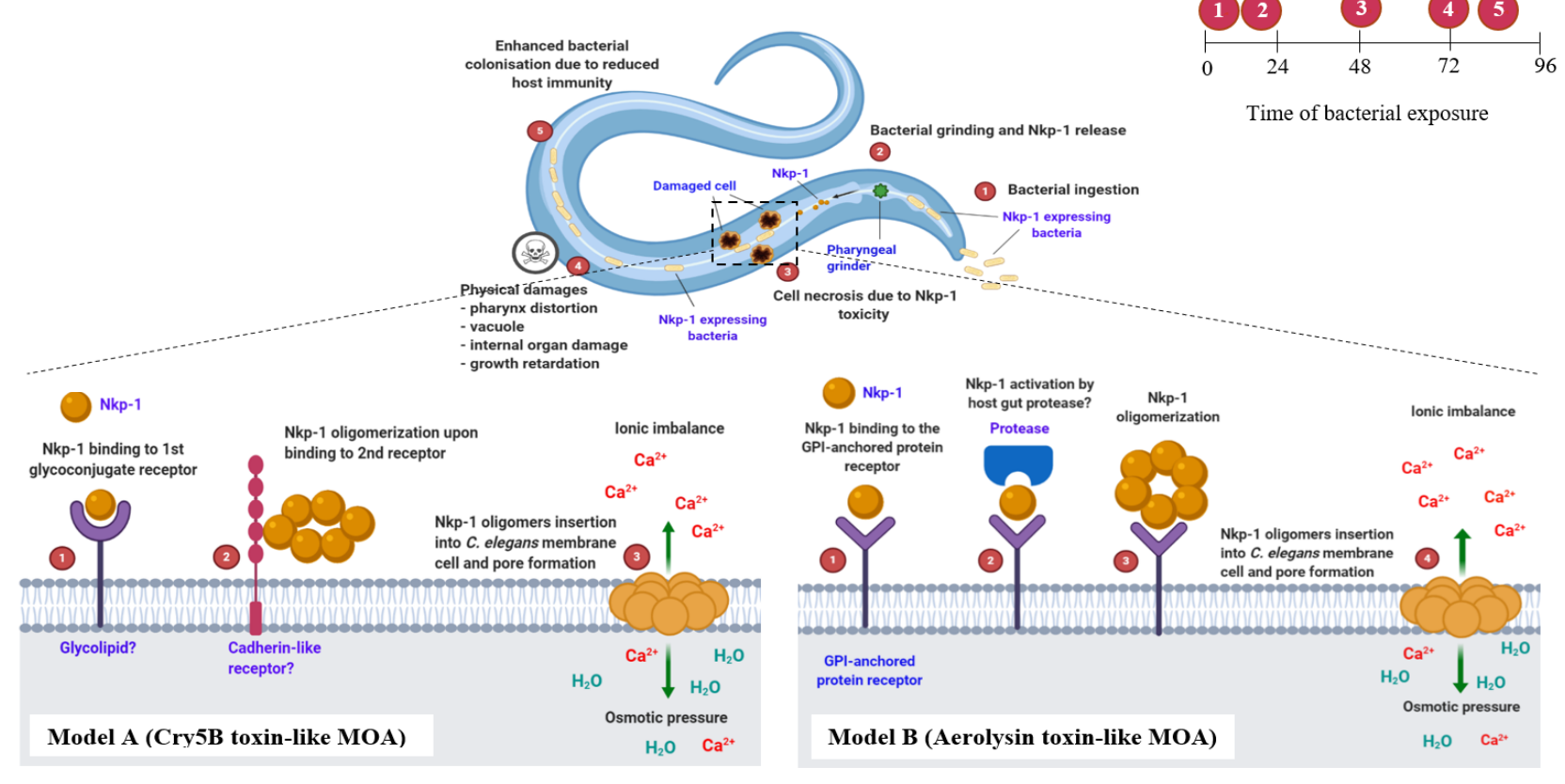

Figure 9. Schematic diagram representing the proposed mode of action (MOA) of Nkp-1 expressing bacteria (HP1 and HG8) against C. elegans. Above, the proposed step by step (numbers 1 to 5 ; circled in red) nematode-killing mechanism of $\mathrm{Nkp}-1$ expressing bacteria in C. elegans body and the time frame (top right) of each $\mathrm{Nkp}-1$ intoxication phase (starting from $0 \mathrm{~h}$ to $96 \mathrm{~h}$ of bacterial exposure). Below, the proposed models A and B of Nkp-1 MOA in causing necrotic cell death in C. elegans gastrointestinal system; see text for more details. Image created with BioRender.com.

Stage 1: Ingestion and digestion of Nkp-1 expressing bacteria by C. elegans. When the pharyngeal muscles contract, bacteria are ingested, concentrated, pulverized (using a "grinder" located in the terminal bulb) and passed into the intestine through the pharyngealintestinal valve for degradation and nutrient absorption $[75,76]$. However, upon ingestion of toxic bacteria, including HP1 and HG8, this grinding activity may also result in the liberation of toxic metabolites, such as Nkp-1 (Figure 9). While future work is required to demonstrate the release of $\mathrm{Nkp}-1$ by the nematode pharyngeal grinder, similar mechanisms have previously been demonstrated for the release of Cry toxin from B. thuringiensis [42,77]. In addition, nematode species lacking the pharyngeal grinder bulb, i.e., Pristionchus pacificus, are resistant to $B$. thuringiensis producing the Cry toxin [78] further suggesting that pharyngeal grinding in C. elegans may enable the release of Nkp-1 from both HP1 and HG8 strains.

Stage 2: Nkp-1 triggers cellular level damage (necrosis) in C. elegans. Upon bacterial ingestion and Nkp-1 liberation, one possibility is that the toxic protein functions as a degradative enzyme targeting $C$. elegans body components; however, as there was no evidence of lipase, protease, chitinase or gelatinase/collagenase activity, an Nkp-1 killing mechanism via degradative enzymatic activity is unlikely. Rather, microscopic observation of nematodes exposed to the Nkp-1 expressing clones suggested that Nkp-1 may function as a pore-forming toxin (PFT) causing necrotic cell death (necrosis), as intestinal cells were permeable to propidium iodide (PI) staining (Figure 5A-F,P) [79,80].

Two different models, Cry5B-like (based on Cry toxin by B. thuringiensis) and aerolysin toxin-like (based on aerolysin toxin by Aeromonas sp.) (Figure 9) [77,81], are proposed to describe the Nkp-1 mode of action. In both models, the Nkp-1 protein is solubilised in the nematode intestine prior to it binding to a yet undetermined glycoconjugate receptor of intestinal cells, for example, the invertebrate-specific glycolipid in Model A [77] or the glycosyl phosphatidyl inositol (GPI)-anchored protein in Model B [81,82] (Figure 9). To activate toxicity, aerolysin needs to be cleaved at the C-termini by the host gut protease $[81,83]$. However, whether Nkp-1 requires proteolytic activation is still unknown. Next, as occurs for both $\mathrm{Cry} 5 \mathrm{~B}$ and aerolysin toxins, the $\mathrm{Nkp}-1$ is predicted to oligomerize, generating 
a ring-like structure inserted into the nematode intestinal cells hence resulting in pore formation (Figure 9). For $\beta$-PFT toxins harbouring an anti-parallel $\beta$-barrel (as displayed by the Nkp-1 3D protein model; see Figure $8 \mathrm{~B}, \mathrm{C}$ ) toxin oligomerisation is a crucial step prior to the oligomers' insertion into the targeted host cell [83]. There is evidence that the cadherin-like receptor in C. elegans facilitates the oligomerization of Cry5B toxin and its formation of pores [84]. However, whether the cadherin-like receptor is required for Nkp-1 oligomerization and pore formation warrants further investigation. Following the insertion of Nkp-1 oligomers, it is proposed that the plasma membrane of nematode intestinal cells is punctured, resulting in vacuole formation due to osmotic imbalance between the cytoplasm and the extracellular environment followed by necrosis and physical damage (Figure 9) $[42,77,84]$.

Stage 3: Nkp-1-expressing bacteria cause physical damage to C. elegans. Exposure of Nkp-1 to C. elegans results in severe growth retardation (see Figure 7E,I). Consistent with this finding, toxic proteins Pp-ANP1a and Pp-ANP2a produced by Pseudomonas protegens and aflatoxin by Aspergillus flavus and Aspergillus parasiticus also caused growth retardation in C. elegans [27,85]. Similarly, exposure to E. coli clones expressing the $B$. thuringiensis Cry21Fa1 or Cry21Ha1 toxins results in reduced body size in C. elegans [86]. Nematode growth retardation upon exposure to these toxins could be a result of reduced nutrient absorption efficiency caused by the perturbed intestinal cells and damaged micro villi [87]. An increase in pharynx distortion was also observed on C. elegans exposed to the Nkp-1-expressing clones and their protein extracts (Figure 4F,K and Figure 7F,K). Pharynx distortion has been associated with "rigor mortis" and increasing cytoplasmic calcium $\left(\mathrm{Ca}^{2+}\right)$ which are the early signs of dying muscle cells due to necrosis in the C. elegans pharyngeal and gastrointestinal system [88]. Whilst pharynx distortion could be an indicator of ageing in nematodes, it also can occur as an immediate impact of bacterial evasion of pharyngeal cells (particularly at the terminal bulb), resulting in nematode mortality [89]. Indeed, other studies have shown an increase in this phenotype because of uncontrolled bacterial proliferation [90]. Vacuole formation and internal body damage (indicated by excessive physical discolouration, shrinking intestine and degenerated gonadal system and germline cells) was also observed in C. elegans exposed to the Nkp-1-expressing clones and their protein extracts (Figures $4 \mathrm{G}$ and $7 \mathrm{E}, \mathrm{G}$ ). Vacuole formation, which may represent swelling necrotic-like cell death [91], is strongly linked to necrosis in C. elegans [92]. Similar phenotypes have been observed for nematodes exposed to microbial pathogens $[93,94]$ and other toxins, including pore-forming toxins (PFTs) such as Cry toxin produced by $B$. thuringiensis [95] and cytolysin produced by $V$. cholerae [93,96].

Stage 4: Enhanced Nkp-1-expressing bacterial colonisation. The intestine not only acts as a site for nutrient absorption but also provides important protective immunity against harmful microorganisms $[97,98]$. Given the important immune function of the intestine, severe intestinal damage as a result of exposure to $\mathrm{Nkp}-1$ may increase the susceptibility of C. elegans to bacterial proliferation and deteriorate its fitness. Indeed, both direct microscopic observation and bacterial CFU counts indicated that $E$. coli cells expressing Nkp-1 are able to proliferate in the intestine of C. elegans (Figure 3, Supplementary Materials Figure S1). This observation could be linked to the MOA of bacteria producing protein toxins, i.e., indirectly hijacking the host immune system and its antimicrobial effectors hence enhancing bacterial colonisation of the host [99]. The result of this proposed MOA for Nkp-1 described above is C. elegans mortality.

\subsection{Dar Formation and Internal Hatching; C. elegans Response against Nkp-1 Expressing Bacteria}

Internal egg hatching was also observed in C. elegans individuals exposed to the Nkp-1 expressing strains or their corresponding protein extracts (Figures 4F,J and 7H,M). This phenotype has been observed in C. elegans challenged with Vibrio parahaemolyticus and when sequentially exposed to Staphylococcus aureus and Proteus mirabilis $[100,101]$ Internal hatching allows the eggs to hatch within parental nematodes and acts to protect progeny against starvation and/or bacterial toxicity [102,103]. However, this phenotype adversely 
diminished the survival of the parent nematode by damaging the gonads resulting in matricidal death [102]. Therefore, it is possible that internal egg hatching occurs as part of a general stress response to $\mathrm{Nkp}-1$ and could be used by C. elegans as a mechanism of maintaining its population.

Notably, the deformed anal region (dar) phenotype or swelling of the anal region was only observed in C. elegans exposed to the HP1 strain (Figure 4H,M). Previous studies have suggested that the dar phenotype acts as an immune response against bacteria as mutants lacking this phenotype experienced high rates of infection [104,105] Dar formation has also been observed in C. elegans exposed to several other microbes including Microbacterium nematophilum [104], Saccharomyces cerevisiae [105] and Coxiella burnetii [106]. Unlike M. nematophilum, which was abundantly found adhering the nematode rectum [107], HP1 colonises the C. elegans intestinal lumen particularly at the anterior region. Similarly, C. elegans exposed to S. cerevisiae and C. burnetii also demonstrated intestinal lumen colonisation but without cell accumulation at the nematode rectum $[105,106]$ It has been previously suggested that the dar phenotype is a mechanism employed by C. elegans to ease bacterial removal from the anal opening through the epithelial rectal swelling mechanism $[104,105,108]$. In addition, nematodes with dar also show an avoidance behaviour against the toxic bacteria that may indirectly facilitate the clearance of toxic bacterial infections from the intestine [108]. Interestingly, the dar phenotype was not seen in C. elegans exposed to HG8. One possible explanation for this observation is that the HP1 bacterial colonisation and its toxic effect is milder compared to the HG8 strains. This observation could be linked to the higher abundance of HG8 bacterial cells in C. elegans compared to the HP1 strain within $24 \mathrm{~h}$ of bacterial exposure (see Figure 3A,B, Supplementary Materials, Figure S1). Consequently, within $24 \mathrm{~h}$, while $50 \%$ of HP1-exposed nematodes showed the dar phenotype, almost half of the HG8-exposed nematodes were severely damaged leading to their rapid death.

\section{Conclusions}

This study has identified the previously uncharacterised protein Nkp-1 as the causative agent for the nematode fast killing activity of the marine bacterium P. tunicata. Nkp1 does not appear to have any enzymatic activity; rather, based on the modelling of a carbohydrate-binding domain, Nkp-1 is hypothesised to act as a novel pore-forming toxin (PFT). Histological observations of C. elegans individuals exposed to Nkp-1, including loss of membrane integrity and necrosis, support the theory of a PFT mode of action. Severe physical damages observed on C. elegans particularly in the intestinal region may reduce nematode immunity, resulting in increased colonisation by the $\mathrm{Nkp}-1$ expressing bacteria and a shortened nematode lifespan.

Whilst the use of Nkp-1 as a future nematicide is promising, more work is required to fully understand its mode of action and safety. For example, the comparative analysis of Nkp-1 to the current nematicide; BT toxin (i.e., Cry5B), via dose-response assay and the analysis of Nkp-1's efficacy against the Cry BT toxin-mutant, i.e., bre nematodes, to confirm its potential binding to the nematode glycoconjugate receptor. Importantly, while $C$. elegans represents a good model system, future investigation of Nkp-1 toxicity against human (e.g., Ancylostoma duodenale, Brugia malayi), animal (e.g., Anisakis simplex, Haemonchus contortus) or plant parasitic nematodes (e.g., Meloidogyne incognita, Radopholus similis) should be performed in vitro and in vivo to understand the broad-scale potential of this new anti-nematode agent. Finally, the cytotoxicity of Nkp-1 in host cell lines and non-target organisms will be an important next step to determine Nkp-1's suitability as an anthelminthic drug. Given the rapid increase in nematode drug resistance, it is hoped that the work presented here will facilitate future developments of Nkp-1 as a novel anti-nematode drug or biopesticide. 
Supplementary Materials: The following are available online at https:/ / www.mdpi.com/article/10 .3390/biomedicines9111586/s1, Figure S1: HP1::GFP and HG8::GFP bacterial colonisation within C. elegans gastrointestinal system, Figure S2: SDS polyacrylamide gel (12\%) showing soluble and insoluble protein fractions of HP1, HG8 and the control strains; BD24 and EPI300.

Author Contributions: N.H.S., M.D., J.N., H.L., C.M. and S.E. developed the conceptual idea. N.H.S. and M.D. ran the experiments. N.H.S. wrote the initial draft. M.D., J.N., H.L., C.M. and S.E. wrote, reviewed and edited the draft. All authors have read and agreed to the published version of the manuscript.

Funding: This research received no external funding.

Institutional Review Board Statement: Not applicable.

Informed Consent Statement: Not applicable.

Data Availability Statement: The data presented in this study are available within this article and the Supplementary Materials.

Acknowledgments: Mass spectrometric analysis for this work was carried out at the Bioanalytical Mass Spectrometry Facility, UNSW, and was supported in part by infrastructure funding from the New South Wales Government as part of its co-investment in the National Collaborative Research Infrastructure Strategy. Authors also would like to thank CMSI staff and students for helpful discussions. Nor Hawani Salikin was supported by the Ministry of Higher Education Malaysia and Universiti Sains Malaysia under the Academic Staff Training Scheme Fellowship.

Conflicts of Interest: The authors declare no conflict of interest.

\section{References}

1. Ziegelbauer, K.; Speich, B.; Mäusezahl, D.; Bos, R.; Keiser, J.; Utzinger, J. Effect of sanitation on soil-transmitted helminth infection: Systematic review and meta-analysis. PLoS Med. 2012, 9, e1001162. [CrossRef]

2. Mahmud, M.A.; Spigt, M.; Bezabih, A.M.; Pavon, I.L.; Dinant, G.-J.; Velasco, R.B. Efficacy of handwashing with soap and nail clipping on intestinal parasitic infections in school-aged children: A factorial cluster randomized controlled trial. PLoS Med. 2015, 12, e1001837. [CrossRef] [PubMed]

3. World Health Organisation. Soil-Transmitted Helminth Infections. Available online: https://www.who.int/news-room/factsheets / detail/soil-transmitted-helminth-infections (accessed on 28 September 2021).

4. Plummer, M.; de Martel, C.; Vignat, J.; Ferlay, J.; Bray, F.; Franceschi, S. Global burden of cancers attributable to infections in 2012: A synthetic analysis. Lancet Glob. Health 2016, 4, e609-e616. [CrossRef]

5. Nicol, J.M.; Turner, S.J.; Coyne, D.L.; den Nijs, L.; Hockland, S.; Maafi, Z.T. Current nematode threats to world agriculture. In Genomics and Molecular Genetics of Plant-Nematode Interactions; Jones, J., Gheysen, G., Fenoll, C., Eds.; Springer: Dordrecht, The Netherlands, 2011. [CrossRef]

6. Coyne, D.L.; Cortada, L.; Dalzell, J.J.; Claudius-Cole, A.O.; Haukeland, S.; Luambano, N.; Talwana, H. Plant-parasitic nematodes and food security in Sub-Saharan Africa. Annu. Rev. Phytopathol. 2018, 56, 381-403. [CrossRef] [PubMed]

7. Becker, S.L.; Liwanag, H.J.; Snyder, J.S.; Akogun, O.; Belizario, V., Jr.; Freeman, M.C.; Gyorkos, T.W.; Imtiaz, R.; Keiser, J.; Krolewiecki, A.; et al. Toward the 2020 goal of soil-transmitted helminthiasis control and elimination. PLoS Negl. Trop. Dis. 2018, 12, e0006606. [CrossRef] [PubMed]

8. Ballesteros, C.; Pulaski, C.N.; Bourguinat, C.; Keller, K.; Prichard, R.K.; Geary, T.G. Clinical validation of molecular markers of macrocyclic lactone resistance in Dirofilaria immitis. Int. J. Parasitol. Drugs Drug Resist. 2018, 8, 596-606. [CrossRef] [PubMed]

9. Holden-Dye, L.; Walker, R. Anthelmintic drugs and nematocides: Studies in Caenorhabditis elegans. In WormBook: The Online Review of C. elegans Biology; The C. elegans Research Community, Ed.; WormBook: Pasadena, CA, USA, 2014; pp. 1-12. [CrossRef]

10. Fanelli, E.; Troccoli, A.; Tarasco, E.; De Luca, F. Molecular characterization and functional analysis of the Hb-Hsp90-1 gene in relation to temperature changes in Heterorhabditis bacteriophora. Front. Physiol. 2021, 12, 136. [CrossRef]

11. Lourenço-Tessutti, I.T.; Souza Junior, J.D.A.; Martins-de-Sa, D.; Viana, A.A.B.; Carneiro, R.M.D.G.; Togawa, R.C.; de AlmeidaEngler, J.; Batista, J.A.N.; Silva, M.C.M.; Fragoso, R.R.; et al. Knock-down of heat-shock protein 90 and isocitrate lyase gene expression reduced root-knot nematode reproduction. Phytopathology 2015, 105, 628-637. [CrossRef]

12. Midkiff, D.; San-Miguel, A. Microfluidic technologies for high throughput screening through sorting and on-chip culture of $C$. elegans. Molecules 2019, 24, 4292. [CrossRef] [PubMed]

13. Giunti, S.; Andersen, N.; Rayes, D.; De Rosa, M.J. Drug discovery: Insights from the invertebrate Caenorhabditis elegans. Pharmacol. Res. Perspect. 2021, 9, e00721. [CrossRef]

14. Romano, G.; Costantini, M.; Sansone, C.; Lauritano, C.; Ruocco, N.; Ianora, A. Marine microorganisms as a promising and sustainable source of bioactive molecules. Mar. Environ. Res. 2017, 128, 58-69. [CrossRef] [PubMed] 
15. Salikin, N.H.; Nappi, J.; Majzoub, M.E.; Egan, S. Combating parasitic nematode infections, newly discovered antinematode compounds from marine epiphytic bacteria. Microorganisms 2020, 8, 1963. [CrossRef]

16. Bernbom, N.; Ng, Y.Y.; Kjelleberg, S.; Harder, T.; Gram, L. Marine bacteria from Danish coastal waters show antifouling activity against the marine fouling bacterium Pseudoalteromonas sp. strain S91 and zoospores of the green alga Ulva australis independent of bacteriocidal activity. Appl. Environ. Microbiol. 2011, 77, 8557-8567. [CrossRef] [PubMed]

17. Paulsen, S.S.; Strube, M.L.; Bech, P.K.; Gram, L.; Sonnenschein, E.C. Marine chitinolytic Pseudoalteromonas represents an untapped reservoir of bioactive potential. mSystems 2019, 4, e00060-19. [CrossRef]

18. Ballestriero, F.; Thomas, T.; Burke, C.; Egan, S.; Kjelleberg, S. Identification of compounds with bioactivity against the nematode Caenorhabditis elegans by a screen based on the functional genomics of the marine bacterium Pseudoalteromonas tunicata D2. Appl. Environ. Microbiol. 2010, 76, 5710-5717. [CrossRef]

19. Franks, A.; Egan, S.; Holmström, C.; James, S.; Lappin-Scott, H.; Kjelleberg, S. Inhibition of fungal colonization by Pseudoalteromonas tunicata provides a competitive advantage during surface colonization. Appl. Environ. Microbiol. 2006, 72, $6079-6087$. [CrossRef]

20. Brenner, S. The genetics of Caenorhabditis elegans. Genetics 1974, 77, 71-94. [CrossRef]

21. Daim, M.F. Characterising the Antinematodal Activity of the Marine Bacterium Pseudoalteromonas tunicata When Screened against Caenorhabditis elegans. Bachelor' Thesis, The University of New South Wales, Sydney, Australia, 2012.

22. Burke, C.; Thomas, T.; Egan, S.; Kjelleberg, S. The use of functional genomics for the identification of a gene cluster encoding for the biosynthesis of an antifungal tambjamine in the marine bacterium Pseudoalteromonas tunicata. Env. Microbiol. 2007, 9, 814-818. [CrossRef] [PubMed]

23. Guzman, L.M.; Belin, D.; Carson, M.J.; Beckwith, J. Tight regulation, modulation, and high-level expression by vectors containing the arabinose PBAD promoter. J. Bacteriol. 1995, 177, 4121-4130. [CrossRef] [PubMed]

24. Stretton, S.; Techkarnjanaruk, S.; McLennan, A.M.; Goodman, A.E. Use of green fluorescent protein to tag and investigate gene expression in marine bacteria. Appl. Env. Microbiol. 1998, 64, 2554-2559. [CrossRef] [PubMed]

25. Stiernagle, T. Maintenance of C. elegans. In WormBook: The Online Review of C. elegans Biology; The C. elegans Research Community, Ed.; WormBook: Pasadena, CA, USA, 2006; pp. 1-11. [CrossRef]

26. Seidman, C.E.; Struhl, K.; Sheen, J.; Jessen, T. Introduction of plasmid DNA into cells. Curr. Protoc. Mol. Biol. 1997, 37, 1-8. [CrossRef]

27. Wei, J.-Z.; Siehl, D.L.; Hou, Z.; Rosen, B.; Oral, J.; Taylor, C.G.; Wu, G. An enterotoxin-like binary protein from Pseudomonas protegens with potent nematicidal activity. Appl. Environ. Microbiol. 2017, 83, e00942-17. [CrossRef]

28. Nappi, J. Discovery of Novel Bioactive Metabolites from Marine Epiphytic Bacteria and Assessment of Their Ecological Role. Ph.D. Thesis, The University of New South Wales, Sydney, Australia, 2019.

29. Sant'anna, V.; Vommaro, R.C.; de Souza, W. Caenorhabditis elegans as a model for the screening of anthelminthic compounds: Ultrastructural study of the effects of albendazole. Exp. Parasitol. 2013, 135, 1-8. [CrossRef] [PubMed]

30. Bischof, L.J.; Huffman, D.; Aroian, R. Assays for toxicity studies in C. elegans with Bt crystal proteins. Methods Mol. Biol. 2006, 351, 139-154. [CrossRef] [PubMed]

31. Garsin, D.A.; Sifri, C.D.; Mylonakis, E.; Qin, X.; Singh, K.V.; Murray, B.E.; Calderwood, S.B.; Ausubel, F.M. A Simple model host for identifying Gram-positive virulence factors. Proc. Natl. Acad. Sci. USA 2001, 98, 10892-10897. [CrossRef]

32. Portal-Celhay, C.; Bradley, E.R.; Blaser, M.J. Control of intestinal bacterial proliferation in regulation of lifespan in Caenorhabditis elegans. BMC Microbiol. 2012, 12, 49. [CrossRef] [PubMed]

33. Galdino, A.C.M.; Branquinha, M.H.; Santos, A.L.S.; Viganor, L. Pseudomonas aeruginosa and its arsenal of proteases: Weapons to battle the host. In Pathophysiological Aspects of Proteases; Chakraborti, S., Dhalla, N., Eds.; Springer: Singapore, 2017 ; pp. 381-397. [CrossRef]

34. Hu, J.; Cai, W.; Wang, C.; Du, X.; Lin, J.; Cai, J. Purification and characterization of alkaline lipase production by Pseudomonas aeruginosa HFE733 and application for biodegradation in food wastewater treatment. Biotechnol. Biotechnol. Equip. 2018, 32, 583-590. [CrossRef]

35. Nursyam, H.; Prihanto, A.A.; Warasari, N.I.; Saadah, M.; Masrifa, R.E.; Nabila, N.A.; Istiqfarin, N.; Siddiq, I.J. The isolation and identification of endophytic bacteria from mangrove (Sonneratia alba) that produces gelatinase. IOP Conf. Ser. Earth Environ. Sci. 2018, 137, 12056. [CrossRef]

36. Sarker, K.N.; Das Mohapatra, P.K.; Dutta, S. Use of low cost natural resources for enhanced chitinase production and optimization using CCD and RSM: A new initiative for bio-control of plant pathogen. Indian Phytopathol. 2019, 72, 281-300. [CrossRef]

37. Waschkowitz, T.; Rockstroh, S.; Daniel, R. Isolation and characterization of metalloproteases with a novel domain structure by construction and screening of metagenomic libraries. Appl. Environ. Microbiol. 2009, 75, 2506-2516. [CrossRef]

38. Balan, S.S.; Nethaji, R.; Sankar, S.; Jayalakshmi, S. Production of gelatinase enzyme from Bacillus spp isolated from the sediment sample of Porto Novo coastal sites. Asian Pac. J. Trop. Biomed. 2012, 2, S1811-S1816. [CrossRef]

39. Samad, M.Y.A.; Razak, C.N.A.; Salleh, A.B.; Yunus, W.Z.W.; Ampon, K.; Basri, M. A plate assay for primary screening of lipase activity. J. Microbiol. Methods 1989, 9, 51-56. [CrossRef]

40. Lamine, B.M.; Lamine, B.M.; Bouziane, A. Optimisation of the chitinase production by Serratia marcescens DSM $30121 \mathrm{~T}$ and biological control of locusts. J. Biotechnol. Biomater. 2012, 2, 3-7. [CrossRef] 
41. Kourtis, N.; Nikoletopoulou, V.; Tavernarakis, N. Small heat-shock proteins protect from heat-stroke-associated neurodegeneration. Nature 2012, 490, 213. [CrossRef]

42. Zhang, F.; Peng, D.; Cheng, C.; Zhou, W.; Ju, S.; Wan, D.; Yu, Z.; Shi, J.; Deng, Y.; Wang, F. Bacillus thuringiensis crystal protein Cry6Aa triggers Caenorhabditis elegans necrosis pathway mediated by aspartic protease (ASP-1). PLoS Pathog. 2016, 12, e1005389. [CrossRef] [PubMed]

43. Bai, Y.; Zhi, D.; Li, C.; Liu, D.; Zhang, J.; Tian, J.; Wang, X.; Ren, H.; Li, H. Infection and immune response in the nematode Caenorhabditis elegans elicited by the phytopathogen Xanthomonas. J. Microbiol. Biotechnol. 2014, 24, 1269-1279. [CrossRef] [PubMed]

44. Waterborg, J.H. The Lowry method for protein quantitation. In The Protein Protocols Handbook, 3rd ed.; Walker, J.M., Ed.; Springer's Humana Press: Totowa, NJ, USA, 2009; pp. 7-10.

45. Cleveland, D.W.; Fischer, S.G.; Kirschner, M.W.; Laemmli, U.K. Peptide mapping by limited proteolysis in sodium dodecyl sulfate and analysis by gel electrophoresis. J. Biol. Chem. 1977, 252, 1102-1106. [CrossRef]

46. Laemmli, U.K.; Favre, M. Maturation of the head of bacteriophage T4: I. DNA packaging events. J. Mol. Biol. 1973, 80, 575-599. [CrossRef]

47. Perkins, D.N.; Pappin, D.J.C.; Creasy, D.M.; Cottrell, J.S. Probability-based protein identification by searching sequence databases using mass spectrometry data. Electrophor. Int. J. 1999, 20, 3551-3567. [CrossRef]

48. Kelley, L.A.; Mezulis, S.; Yates, C.M.; Wass, M.N.; Sternberg, M.J.E. The Phyre2 web portal for protein modeling, prediction and analysis. Nat. Protoc. 2015, 10, 845. [CrossRef] [PubMed]

49. Waterhouse, A.; Bertoni, M.; Bienert, S.; Studer, G.; Tauriello, G.; Gumienny, R.; Heer, F.T.; de Beer, T.A.P.; Rempfer, C.; Bordoli, L.; et al. SWISS-MODEL: Homology modelling of protein structures and complexes. Nucleic Acids Res. 2018, 46, W296-W303. [CrossRef] [PubMed]

50. Mantel, N. Evaluation of survival data and two new rank order statistics arising in its consideration. Cancer Chemother. Rep. 1966, 50, 163-170.

51. Harrington, D. Linear rank tests in survival analysis. In Encyclopedia of Biostatistics; John Wiley \& Sons, Ltd.: Hoboken, NJ, USA, 2005. [CrossRef]

52. Moustafa, I.; Connaris, H.; Taylor, M.; Zaitsev, V.; Wilson, J.C.; Kiefel, M.J.; Von Itzstein, M.; Taylor, G. Sialic acid recognition by Vibrio cholerae neuraminidase. J. Biol. Chem. 2004, 279, 40819-40826. [CrossRef] [PubMed]

53. Neal, C.J.; Jobling, M.G.; Holmes, R.K.; Hol, W.G.J. Structural biology: Structural basis for the activation of cholera toxin by human ARF6-GTP. Science 2005, 309, 1093-1096. [CrossRef]

54. Van Bueren, A.L.; Morland, C.; Gilbert, H.J.; Boraston, A.B. Family 6 carbohydrate binding modules recognize the non reducing end of beta-1,3-linked glucans by presenting a unique ligand binding surface. J. Biol. Chem. 2005, 280, 530-537. [CrossRef]

55. Fujimoto, Z.; Suzuki, N.; Kishine, N.; Ichinose, H.; Momma, M.; Kimura, A.; Funane, K. Carbohydrate-binding architecture of the multi-modular $\alpha$-1, 6-glucosyltransferase from Paenibacillus sp. 598K, which produces $\alpha$-1, 6-glucosyl- $\alpha$-glucosaccharides from starch. Biochem. J. 2017, 474, 2763-2778. [CrossRef] [PubMed]

56. Di Tommaso, P.; Moretti, S.; Xenarios, I.; Orobitg, M.; Montanyola, A.; Chang, J.-M.; Taly, J.-F.; Notredame, C. T-Coffee: A web server for the multiple sequence alignment of protein and RNA sequences using structural information and homology extension. Nucleic Acids Res. 2011, 39, W13-W17. [CrossRef]

57. Rahul, S.; Chandrashekhar, P.; Hemant, B.; Chandrakant, N.; Laxmikant, S.; Satish, P. Nematicidal activity of microbial pigment from Serratia marcescens. Nat. Prod. Res. 2014, 28, 1399-1404. [CrossRef] [PubMed]

58. Charuchaibovorn, S.; Sanprasert, V.; Sutthanont, N.; Hu, Y.; Abraham, A.; Ostroff, G.R.; Aroian, R.V.; Jaleta, T.G.; Lok, J.B.; Nuchprayoon, S. Bacillus thuringiensis Cry5B is active against Strongyloides stercoralis in vitro. Am. J. Trop. Med. Hyg. 2019, 101, 1177-1182. [CrossRef]

59. Cantarel, B.L.; Coutinho, P.M.; Rancurel, C.; Bernard, T.; Lombard, V.; Henrissat, B. The Carbohydrate-Active EnZymes Database (CAZy): An expert resource for glycogenomics. Nucleic Acids Res. 2008, 37, D233-D238. [CrossRef] [PubMed]

60. Sainz-Polo, M.A.; Valenzuela, S.V.; González, B.; Pastor, F.I.J.; Sanz-Aparicio, J. Structural analysis of glucuronoxylan-specific Xyn30D and its attached CBM35 domain gives insights into the role of modularity in specificity. J. Biol. Chem. 2014, 289, 31088-31101. [CrossRef]

61. Zhang, X.; Rogowski, A.; Zhao, L.; Hahn, M.G.; Avci, U.; Knox, J.P.; Gilbert, H.J. Understanding how the complex molecular architecture of mannan-degrading hydrolases contributes to plant cell wall degradation. J. Biol. Chem. 2014, 289, $2002-2012$. [CrossRef]

62. Katsimpouras, C.; Dimarogona, M.; Petropoulos, P.; Christakopoulos, P.; Topakas, E. A thermostable GH26 endo- $\beta$-mannanase from Myceliophthora thermophila capable of enhancing lignocellulose degradation. Appl. Microbiol. Biotechnol. 2016, 100, 8385-8397. [CrossRef] [PubMed]

63. Teh, A.-H.; Fazli, N.H.; Furusawa, G. Crystal structure of a neoagarobiose-producing GH16 family $\beta$-agarase from Persicobacter sp. CCB-QB2. Appl. Microbiol. Biotechnol. 2019, 104, 633-641. [CrossRef] [PubMed]

64. Yano, S.; Suyotha, W.; Oguro, N.; Matsui, T.; Shiga, S.; Itoh, T.; Hibi, T.; Tanaka, Y.; Wakayama, M.; Makabe, K. Crystal structure of the catalytic unit of GH 87-type $\alpha$-1,3-glucanase Agl-KA from Bacillus circulans. Sci. Rep. 2019, 9, 15295. [CrossRef]

65. Feng, D.; Chen, Z.; Wang, Z.; Zhang, C.; He, K.; Guo, S. Domain III of Bacillus thuringiensis Cry1Ie toxin plays an important role in binding to peritrophic membrane of Asian corn borer. PLoS ONE 2015, 10, e0136430. [CrossRef] [PubMed] 
66. Rodríguez-González, Á.; Porteous-Álvarez, A.J.; Del Val, M.; Casquero, P.A.; Escriche, B. Toxicity of five Cry proteins against the insect pest Acanthoscelides obtectus (Coleoptera: Chrisomelidae: Bruchinae). J. Invertebr. Pathol. 2020, 169, 107295. [CrossRef] [PubMed]

67. Michel, G.; Barbeyron, T.; Kloareg, B.; Czjzek, M. The family 6 carbohydrate-binding modules have coevolved with their appended catalytic modules toward similar substrate specificity. Glycobiology 2009, 19, 615-623. [CrossRef] [PubMed]

68. Berninsone, P.M. Carbohydrates and glycosylation. In WormBook: The Online Review of C. elegans Biology; The C. elegans Research Community, Ed.; WormBook: Pasadena, CA, USA, 2018. [CrossRef]

69. Jing, X.; Yuan, Y.; Wu, Y.; Wu, D.; Gong, P.; Gao, M. Crystal structure of Bacillus thuringiensis Cry7Ca1 toxin active against Locusta migratoria manilensis. Protein Sci. 2019, 28, 609-619. [CrossRef]

70. Liu, Y.; Zhou, Z.; Wang, Z.; Zhong, B.; Shu, C.; Zhang, J. Replacement of loop2 and 3 of Cry1Ai in domain II affects specificity to the economically important insect Bombyx mori. J. Invertebr. Pathol. 2020, 169, 107296. [CrossRef] [PubMed]

71. Deist, B.R.; Rausch, M.A.; Fernandez-Luna, M.T.; Adang, M.J.; Bonning, B.C. Bt toxin modification for enhanced efficacy. Toxins 2014, 6, 3005-3027. [CrossRef] [PubMed]

72. Karlova, R.; Weemen-Hendriks, M.; Naimov, S.; Ceron, J.; Dukiandjiev, S.; de Maagd, R.A. Bacillus thuringiensis $\delta$-endotoxin Cry1Ac domain III enhances activity against Heliothis virescens in some, but not all Cry1-Cry1Ac hybrids. J. Invertebr. Pathol. 2005, 88, 169-172. [CrossRef] [PubMed]

73. López Pazos, S.A. Three-dimensional structure of Bacillus thuringiensis toxins: A review. Acta Biológica Colomb. 2007, 12, 19-32.

74. Jankowska, E.; Parsons, L.M.; Song, X.; Smith, D.F.; Cummings, R.D.; Cipollo, J.F. A Comprehensive Caenorhabditis elegans N-Glycans shotgun array. Glycobiology 2018, 28, 223-232. [CrossRef] [PubMed]

75. Albertson, D.G.; Thompson, J.N. The pharynx of Caenorhabditis elegans. Philos. Trans. R. Soc. London. B Biol. Sci. 1976, 275, 299-325. [CrossRef] [PubMed]

76. Avery, L.; Shtonda, B.B. Food transport in the C. elegans pharynx. J. Exp. Biol. 2003, 206, 2441-2457. [CrossRef] [PubMed]

77. Griffitts, J.S.; Haslam, S.M.; Yang, T.; Garczynski, S.F.; Mulloy, B.; Morris, H.; Cremer, P.S.; Dell, A.; Adang, M.J.; Aroian, R.V. Glycolipids as receptors for Bacillus thuringiensis crystal toxin. Science 2005, 307, 922-925. [CrossRef]

78. Wei, J.-Z.; Hale, K.; Carta, L.; Platzer, E.; Wong, C.; Fang, S.-C.; Aroian, R.V. Bacillus thuringiensis crystal proteins that target nematodes. Proc. Natl. Acad. Sci. USA 2003, 100, 2760-2765. [CrossRef] [PubMed]

79. Timmons, A.K.; Meehan, T.L.; Gartmond, T.D.; McCall, K. Use of necrotic markers in the Drosophila ovary. In Necrosis: Methods in Molecular Biology; McCall, K., Klein, C., Eds.; Springer's Humana Press: Totowa, NJ, USA, 2013; Volume 1004, pp. $215-228$. [CrossRef]

80. Dementiev, A.; Board, J.; Sitaram, A.; Hey, T.; Kelker, M.S.; Xu, X.; Hu, Y.; Vidal-Quist, C.; Chikwana, V.; Griffin, S.; et al. The pesticidal Cry6Aa toxin from Bacillus thuringiensis is structurally similar to HlyE-family alpha pore-forming toxins. BMC Biol. 2016, 14, 71. [CrossRef]

81. Szczesny, P.; Iacovache, I.; Muszewska, A.; Ginalski, K.; van der Goot, F.G.; Grynberg, M. Extending the aerolysin family: From bacteria to vertebrates. PLoS ONE 2011, 6, e20349. [CrossRef] [PubMed]

82. Cowell, S.; Aschauer, W.; Gruber, H.J.; Nelson, K.L.; Buckley, J.T. The erythrocyte receptor for the channel-forming toxin aerolysin is a novel glycosylphosphatidylinositol-anchored protein. Mol. Microbiol. 1997, 25, 343-350. [CrossRef] [PubMed]

83. Iacovache, I.; van der Goot, F.G.; Pernot, L. Pore formation: An ancient yet complex form of attack. Biochim. Biophys. Acta Biomembr. 2008, 1778, 1611-1623. [CrossRef]

84. Peng, D.; Wan, D.; Cheng, C.; Ye, X.; Sun, M. Nematode-specific cadherin CDH-8 acts as a receptor for Cry5B toxin in Caenorhabditis elegans. Appl. Microbiol. Biotechnol. 2018, 102, 3663-3673. [CrossRef] [PubMed]

85. Feng, W.-H.; Xue, K.S.; Tang, L.; Williams, P.L.; Wang, J.-S. Aflatoxin B(1)-induced developmental and DNA damage in Caenorhabditis elegans. Toxins 2017, 9, 9. [CrossRef]

86. Iatsenko, I.; Boichenko, I.; Sommer, R.J. Bacillus thuringiensis DB27 produces two novel protoxins, Cry21Fa1 and Cry21Ha1, which act synergistically against nematodes. Appl. Environ. Microbiol. 2014, 80, 3266-3275. [CrossRef] [PubMed]

87. Marroquin, L.D.; Elyassnia, D.; Griffitts, J.S.; Feitelson, J.S.; Aroian, R.V. Bacillus thuringiensis (Bt) toxin susceptibility and isolation of resistance mutants in the nematode Caenorhabditis elegans. Genetics 2000, 155, 1693-1699. [CrossRef]

88. Galimov, E.R.; Pryor, R.E.; Poole, S.E.; Benedetto, A.; Pincus, Z.; Gems, D. Coupling of rigor mortis and intestinal necrosis during C. elegans organismal death. Cell Rep. 2018, 22, 2730-2741. [CrossRef] [PubMed]

89. Zhao, Y.; Gilliat, A.F.; Ziehm, M.; Turmaine, M.; Wang, H.; Ezcurra, M.; Yang, C.; Phillips, G.; McBay, D.; Zhang, W.B. Two forms of death in ageing Caenorhabditis elegans. Nat. Commun. 2017, 8, 15458. [CrossRef]

90. Haskins, K.A.; Russell, J.F.; Gaddis, N.; Dressman, H.K.; Aballay, A. Unfolded protein response genes regulated by CED-1 are required for Caenorhabditis elegans innate immunity. Dev. Cell 2008, 15, 87-97. [CrossRef] [PubMed]

91. Xu, K.; Tavernarakis, N.; Driscoll, M. Necrotic cell death in C. elegans requires the function of calreticulin and regulators of Ca ${ }^{2+}$ release from the endoplasmic reticulum. Neuron 2001, 31, 957-971. [CrossRef]

92. Nikoletopoulou, V.; Tavernarakis, N. Chapter Six-Necrotic cell death in Caenorhabditis elegans. In Methods in Enzymology; Ashkenazi, A., Wells, J.A., Yuan, J., Eds.; Academic Press: Cambridge, MA, USA, 2014; Volume 545, pp. 127-155. [CrossRef]

93. Durai, S.; Balamurugan, K. Vibrio: Caenorhabditis elegans as a laboratory model for Vibrio infections. In Laboratory Models for Foodborne Infections, 1st ed.; Liu, D., Ed.; CRC Press: Boca Raton, FL, USA, 2017; p. 413. 
94. Somasiri, P.; Behm, C.A.; Adamski, M.; Wen, J.; Verma, N.K. Transcriptional response of Caenorhabditis elegans when exposed to Shigella flexneri. Genomics 2020, 112, 774-781. [CrossRef]

95. Brito, C.; Cabanes, D.; Sarmento Mesquita, F.; Sousa, S. Mechanisms protecting host cells against bacterial pore-forming toxins. Cell. Mol. Life Sci. 2019, 76, 1319-1339. [CrossRef] [PubMed]

96. Cinar, H.N.; Kothary, M.; Datta, A.R.; Tall, B.D.; Sprando, R.; Bilecen, K.; Yildiz, F.; McCardell, B. Vibrio cholerae hemolysin is required for lethality, developmental delay, and intestinal vacuolation in Caenorhabditis elegans. PLoS ONE 2010, 5, e11558. [CrossRef] [PubMed]

97. Irazoqui, J.E.; Urbach, J.M.; Ausubel, F.M. Evolution of host innate defence: Insights from Caenorhabditis elegans and primitive invertebrates. Nat. Rev. Immunol. 2010, 10, 47. [CrossRef] [PubMed]

98. Pukkila-Worley, R.; Ausubel, F.M. Immune defense mechanisms in the Caenorhabditis elegans intestinal epithelium. Curr. Opin. Immunol. 2012, 24, 3-9. [CrossRef] [PubMed]

99. Los, F.C.O.; Randis, T.M.; Aroian, R.V.; Ratner, A.J. Role of pore-forming toxins in bacterial infectious diseases. Microbiol. Mol. Biol. Rev. 2013, 77, 173. [CrossRef]

100. Sellegounder, D.; Pandian, S.; Balamurugan, K. Changes in Caenorhabditis elegans exposed to Vibrio Parahaemolyticus. J. Microbiol. Biotechnol. 2011, 21, 1026-1035. [CrossRef]

101. JebaMercy, G.; Balamurugan, K. Effects of sequential infections of Caenorhabditis elegans with Staphylococcus aureus and Proteus mirabilis. Microbiol. Immunol. 2012, 56, 825-835. [CrossRef]

102. Mosser, T.; Matic, I.; Leroy, M. Bacterium-induced internal egg hatching frequency is predictive of life span in Caenorhabditis elegans populations. Appl. Environ. Microbiol. 2011, 77, 8189-8192. [CrossRef]

103. De Souza, C.; Simpson-Louredo, L.; Mota, H.F.; Faria, Y.V.; de Oliveira Cabral, F.; dos Santos Colodette, S.; Canellas, M.E.F.C.; Cucinelli, A.D.E.S.; de Luna, M.D.G.; Santos, C.D.S.; et al. Virulence potential of Corynebacterium striatum towards Caenorhabditis elegans. Antonie Leeuwenhoek 2019, 112, 1331-1340. [CrossRef]

104. Hodgkin, J.; Kuwabara, P.E.; Corneliussen, B. A novel bacterial pathogen, Microbacterium nematophilum, induces morphological change in the nematode C. elegans. Curr. Biol. 2000, 10, 1615-1618. [CrossRef]

105. Jain, C.; Yun, M.; Politz, S.M.; Rao, R.P. A pathogenesis assay using Saccharomyces cerevisiae and Caenorhabditis elegans reveals novel roles for yeast AP-1, Yap1, and host dual oxidase BLI-3 in fungal pathogenesis. Eukaryot Cell 2009, 8, 1218-1227. [CrossRef] [PubMed]

106. Battisti, J.M.; Watson, L.A.; Naung, M.T.; Drobish, A.M.; Voronina, E.; Minnick, M.F. Analysis of the Caenorhabditis elegans innate immune response to Coxiella burnetii. Innate Immun. 2017, 23, 111-127. [CrossRef] [PubMed]

107. Nicholas, H.R.; Hodgkin, J. The ERK MAP Kinase cascade mediates tail swelling and a protective response to rectal infection in $C$. elegans. Curr. Biol. 2004, 14, 1256-1261. [CrossRef] [PubMed]

108. Anderson, A.; Chew, Y.L.; Schafer, W.; McMullan, R. Identification of a conserved, orphan G protein-coupled receptor required for efficient pathogen clearance in Caenorhabditis elegans. Infect. Immun. 2019, 87, e00034-19. [CrossRef] [PubMed] 